\title{
Food and technical exploitation of mammals during the early Upper Palaeolithic at Les Abeilles (Haute-Garonne, France)
}

L'exploitation alimentaire et technique du gibier au début du Paléolithique supérieur aux Abeilles (Haute-Garonne, France)

\section{Marie-Cécile Soulier}

\section{OpenEdition}

\section{Journals}

\section{Electronic version}

URL: http://journals.openedition.org/paleo/3018

DOI: 10.4000/paleo.3018

ISSN: 2101-0420

\section{Publisher}

SAMRA

\section{Printed version}

Date of publication: 28 December 2014

Number of pages: 287-307

ISSN: $1145-3370$

Electronic reference

Marie-Cécile Soulier, «Food and technical exploitation of mammals during the early Upper Palaeolithic at Les Abeilles (Haute-Garonne, France) », PALEO [Online], 25 | 2014, Online since 28 July 2015 connection on 07 July 2020. URL : http://journals.openedition.org/paleo/3018 ; DOI : https://doi.org/ 10.4000/paleo.3018

This text was automatically generated on 7 July 2020. 


\title{
Food and technical exploitation of mammals during the early Upper Palaeolithic at Les Abeilles (Haute- Garonne, France)
}

\author{
L'exploitation alimentaire et technique du gibier au début du Paléolithique \\ supérieur aux Abeilles (Haute-Garonne, France)
}

Marie-Cécile Soulier

The present study received financial support from the laboratory TRACES-UMR 5608, the French Ministry of Higher Education and Research and the Social Sciences and Humanities Research Council of the Canadian Government (SSHRC) through the project supported by E. Morin "Reassessing the Chronology, Composition and Climatic Implications of three Neanderthal and Early Modern Human Sites from France." I am grateful to Mr. Crémilleux for the access authorization to the collection, and the National Museum of Prehistory of Les Eyzies-de-Tayac that hosts the collection from Les Abeilles. I thank the museum staff for contributing to the success of this study, as well as François Bon, Elise Tartar and Laura Eizenberg for our discussions that have greatly contributed to a better understanding of the site.

\section{Introduction}

1 In Western Europe, the early Upper Palaeolithic was marked by deep changes within industries, some of which were directly related to the exploitation of preys. Indeed, new hunting weapons appeared (e.g. Pelegrin 1990; Bon 2002; Bordes 2002; Normand 2005; Teyssandier 2007; Bachellerie 2011; Roussel 2011) and animals became a source of raw material for the production of tools and ornaments (e.g. Leroy-Prost 1974, 1975, 1979; Taborin 1990, 2002; Knecht 1991, 1993; Liolios 1999 2006; Julien, Baffier, Liolios 2002; Vanhaeren 2002; White 2002, 2010; Tartar 2009; Soulier et al. 2014). However, archaeozoological studies are rare for the initial phases of the Upper Palaeolithic 
(Sekhr 1998; Letourneux 2003; Castel 2011; Soulier 2013), which is largely due to the many limitations of the available corpus (taphonomic problems, old age of the excavations).

2 Les Abeilles site (Montmaurin, Haute-Garonne) is emblematic because the Protoaurignacian was first recognised there (Laplace 1966). The site yielded archaeological layers attributed to the Protoaurignacian and the Early Aurignacian. The lithic industries have recently been re-analysed (Eizenberg 2006; Bon 2011pers. comm.) and the abundant faunal remains collected correspond to both food waste and transformed parts (bone tools, ornaments). Thus, the faunal material from Les Abeilles offers the opportunity to better understand the prey exploitation strategies for this pivotal period of Prehistory.

3 Through archaeozoological studies that include all the faunal remains (remains from food, industry in hard animal matter and ornaments), this paper aims to document the faunal exploitation strategies operated by the human groups that occupied Les Abeilles site at the beginning of the Upper Palaeolithic. The comparison of data from the assemblages attributed to the Protoaurignacian and the Early Aurignacian thus allows discussing possible differences in prey food exploitation methods during the Protoaurignacian and the Early Aurignacian. Considering all the faunal remains also allows to question the links between the technical, ornamental food spheres.

\section{2 - General presentation of the site}

Les Abeilles cave (fig. 1a) is located in the limestone massif of Lespugue-Montmaurin in Haute-Garonne (Méroc 1963). The site environment is of low elevations and hilly areas, but the cave opens up into the steep reliefs of the Seygouade gorges. The cave is southwest facing and corresponds to a gallery subdivided into two chambers (fig. 1b).

5 Two surveys-one in 1945 and one in 1947 (Méroc 1948)-were conducted by R. Cammas, the site's inventor. The cave was then excavated between 1948 and 1951 over circa 22 square meters, at the entrance and inside the cave. A stratigraphy nearly 1.50 $\mathrm{m}$ high was unearthed (fig. 2), within which three techno-complexes were distinguished (Laplace et al. 2006): Mousterian (c. 4), Protoaurignacian (c. 3 and 2) and Early Aurignacian (c. 1). A recent analysis of the stratigraphy and of the field notebooks highlighted the difficulties encountered by the excavators to recognize the Protoaurignacian during the early days of the excavation (Eizenberg 2006). Although two field notebooks exist (including an almost blank one), the excavation methods are not detailed, but we do know that a grid was set up. L. Méroc was excavating the Montmaurin caves at the same time, which had allowed R. Cammas to be familiar with the excavation method based on the use of Cartesian coordinates (Laplace and Méroc 1954). In this method, sieving is recommended (Laplace 1971). If the field notebooks do not mention this practice, the presence of many small lithic objects suggests that at least some areas were sieved (Eizenberg 2006).

6 Some human teeth were collected in both Aurignacian assemblages but none allows a specific attribution (Gambier 1992).

7 The abundant lithic material collected at Les Abeilles was initially analysed by G. Laplace (1966) and this material enabled him to define the Protoaurignacian for the first time. The lithic material of layer 2 (Protoaurignacian) has recently been subjected 
to a detailed typo-technological study (Eizenberg 2006) and a survey of layer 1 (Early Aurignacian) has been carried out (Bon 2011 pers. comm.). Both studies document a toolkit essentially made in local raw material, from the Seygouade Valley (Simonnet 1979). This raw material was used to produce makeshift and little retouched tools (Eizenberg 2006; Bon pers. comm. 2011). Some rare tools, made in raw material from distant sources (e.g. Chalosse, Salies type in Bidache), show a stronger technical investment and appear to have been imported as finished products (op. cit.). Beside differences typically highlighted in the debitage schemes between Protoaurignacian and Early Aurignacian (e.g. Bon 2002; Bordes 2002; Teyssandier 2007), both assemblages are distinct in terms of conservation, with a Protoaurignacian layer strongly affected by mechanical retouching (Eizenberg 2006) that contrasts with much fresher surface states in the Early Aurignacian layer (Bon 2011 pers. comm.).

Several bone tools and ornaments have been discovered at Les Abeilles and have been described by I. Barandiaran (2006). Five objects were collected from the layer attributed to the Protoaurignacian: two likely smoothers, a flat object, a split-based point and a rectangular pendant in bone. The assemblage attributed to the Early Aurignacian yielded 48 bone tools that consist of six split-based points found virtually whole (plus two fragments), antler and bone points, smoothers, a "sharpened splinter in bone", two retouchers and an ivory fragment described as a likely pierced baton fragment. Several debitage waste are present, including those relating to the extraction of rods from antler. Two pendants made on medium size carnivore canines, one on a medium size herbivore incisor and two perforated ivory plaquettes have also been described (Bandiaran 2006).

9 The faunal remains were subjected to a first anatomical and specific determination by J. Altuna (2006). This study, which covers 294 remains for the Protoaurignacian and 477 for the Early Aurignacian, indicates that ungulates and carnivores are present in equal proportions in both assemblages. In this study, the trio Reindeer-Horse-Bovines constitutes the majority of the ungulates, and is associated with the Red deer, the Ibex, the Izard, the Wild boar and, in layer 1, potentially to the Megaloceros. The most common carnivores are the Fox, the Bear and, to a lesser extent, the Hyena. The Bear is particularly abundant throughout the Protoaurignacian assemblage as it makes up to $22.4 \%$ of the faunal spectrum; the Fox represents $24.9 \%$ of the identified remains in the Early Aurignacian. 
Figure 1 - a) Location of Les Abeilles and b) layout of the cave and excavation grid (modified from Laplace et al. 2006). The second test pit is shown in grey.

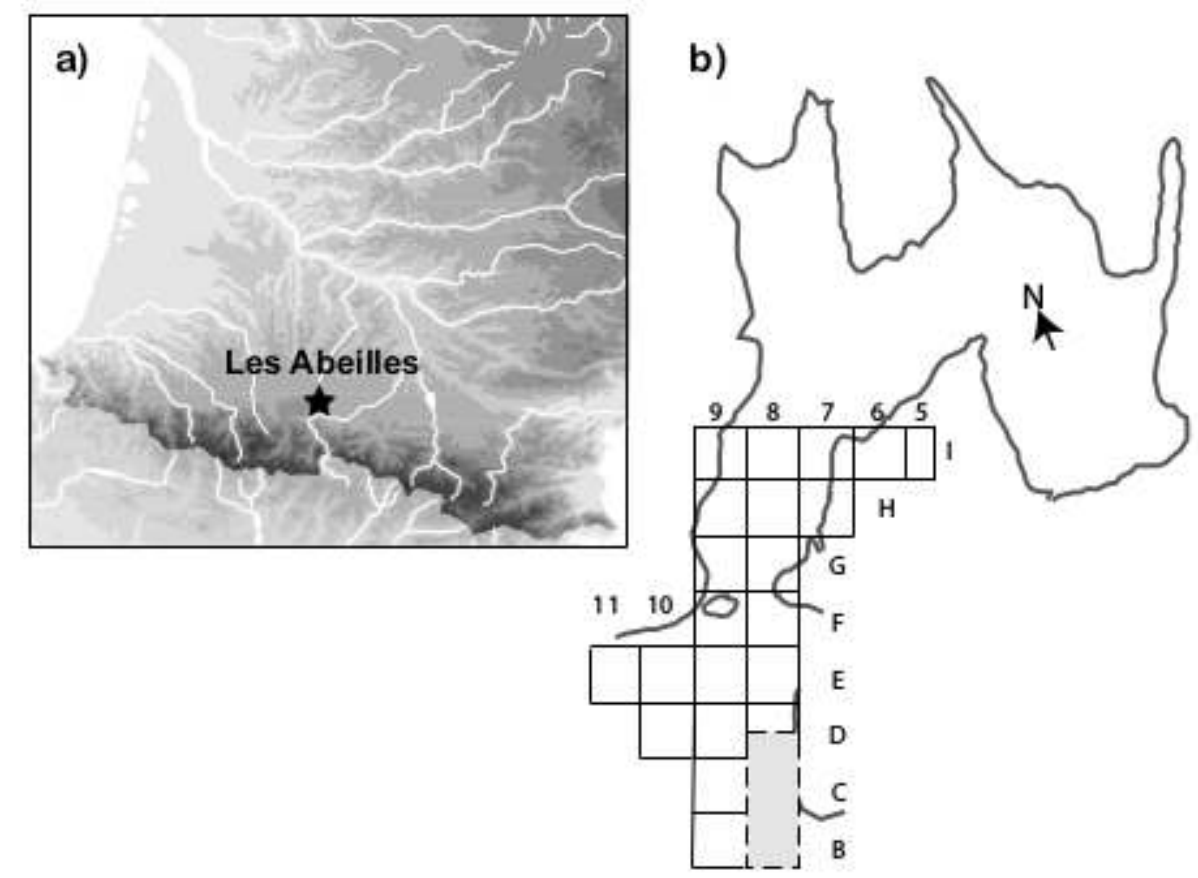

\section{3 - Presentation of the analytical methods and of the corpus}

The anatomical and specific determining was done using the reference collection of the National Museum of Prehistory in Les Eyzies-de-Tayac. The faunal remains that could not be precisely determined were allocated to size classes. The Number of SPecimens $(\mathrm{NSP})^{2}$, the total Number of SPecimens (tNSP), the Number of Identified SPecimens (NISP), the Minimal Animal Units (MAU) and the Minimal Number of Individuals (MNI) were calculated. The calculation of the MNI takes into account the age and lateralization data. Each determinable or above $2 \mathrm{~cm}$ remain was observed under a magnifying glass (x30 magnification) while smaller remains were only subjected to naked eye observation. Climato-edaphic and manducation damages, as well as marks related to human activity (e.g. Fischer 1995) were recorded. Analysis of the fracture edges was carried out according to the criteria proposed by Villa and Mahieu (1991). The age at death of the preys was estimated from use-wear and tooth eruption sequences (Miller 1974; Frison, Wilson M., Wilson D.J. 1976; Levine 1979; Bignon 2006). Hunting seasons were evaluated from the observation of deciduous teeth (Miller 1974; Brugal and David 1993; Bignon 2006) and foetal bones (Habermehl 1975; Roine, Nieminen, Timisjävi 1982). Skeletal representations were confronted-through Spearman (rs) correlation tests-to the density of the various bone portions (after Kreutzer 1992; Lam et al. 1999) and to the indices of nutritional usefulness (Metcalfe and Jones 1988; Emerson 1990; Outram and Rowley-Conwy 1998; Morin 2007). The quantification of butchery cutmarks was done from the Number of SPecimens with Observable surface (NSPo) only and includes dental remains. The activities that created the butchery cutmarks were inferred through the compilation of experimental and ethnographic butchery references (Binford 1981; Bez 1995; Nilssen 2000; Vigne 2005; 
Costamagno and David 2009; Thiébaut et al. 2011)3. The calculation of percussion evidences was done by using the total number of specimens of bones with medullar cavity (mandible, humerus, radio-ulna, femur, tibia, indeterminate long bones, metapodial, first and second phalanges). The burnt bones were classified by degree of combustion, size and tissue type to determine their origin (accidental, fuel, etc.: Costamagno et al. 2009). The "distal burns" (light heating traces at the bones extremities: e.g. Vigne et al. 1981) were also noted.

11 The faunal material presented here corresponds to the Protoaurignacian (c. 2 and 3) and the Early Aurignacian (c. 1). Layers 2 and 3 have been combined for the study because layer 3 would correspond to the base of layer 2 (Laplace et al. 2006). Because of recognition problems in the early excavations for the Protoaurignacian layers (Eizenberg 2006), some squares were excluded from the analysis (details in Soulier 2013). In total, 2,561 faunal specimens were studied for the assemblage attributed to the Protoaurignacian and 12,281 for the Early Aurignacian. These remains include food waste, industry on hard animal matter and ornamentation elements.

Figure 2 - Frontal profile of the cave of Les Abeilles (modified from Laplace et al. 2006).

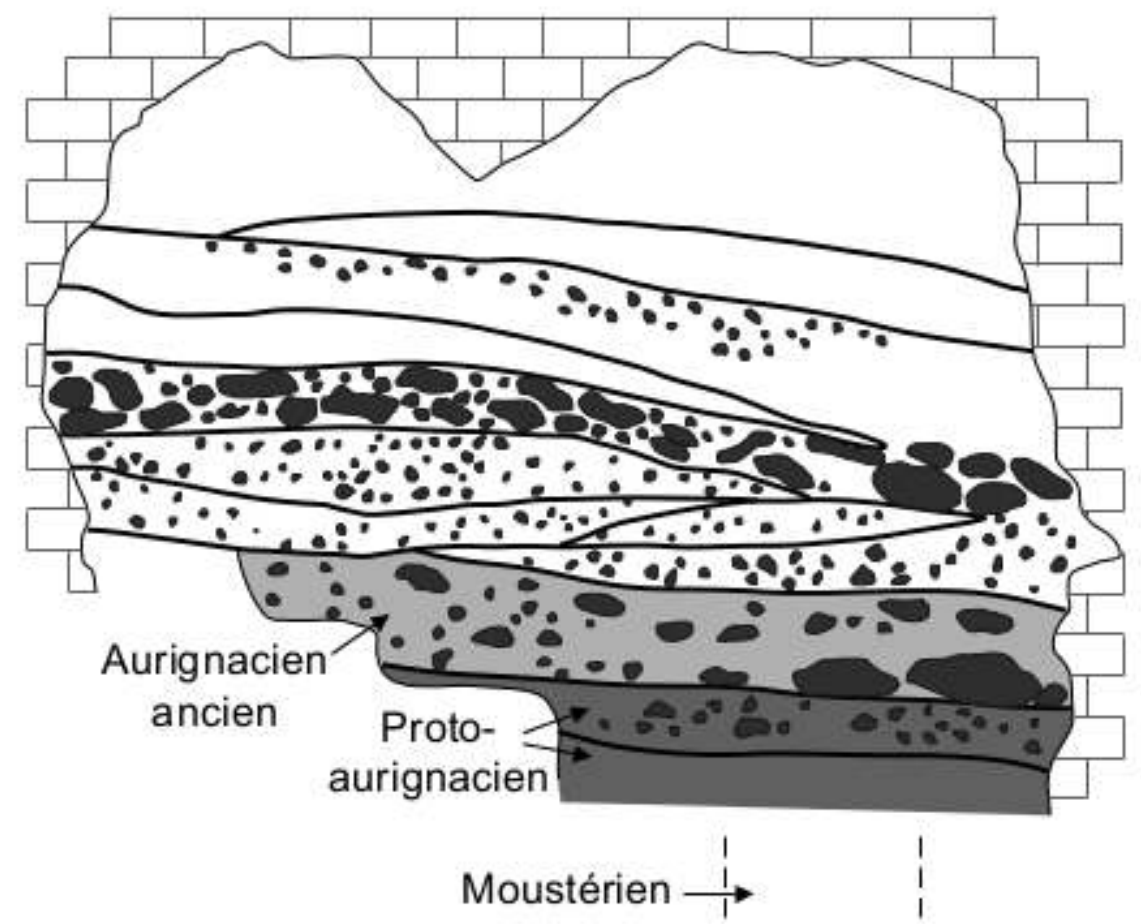

\section{4 - Results}

\section{1 - Taphonomy}

Both assemblages are highly fragmented, with over half of the remains under $2.5 \mathrm{~cm}$ (fig. 3a). The presence of objects under $1 \mathrm{~cm}$ comforts, to some extent, the hypothesis of an excavation with sieving. Whole bones with marrow cavity are rare and the fracture edges indicate that fragmentation mainly occurred on fresh bones (fig. 3b). No inter- 
layer refitting has been identified; when indications of provenience are available, the refitting systematically involves remains from the same square (Soulier 2013).

The majority of bone surfaces are free of any alteration in both assemblages (58\% in the Protoaurignacian and $57 \%$ for the Early Aurignacian). Because many remains are abraded, $30 \%$ of the tNSP attributed to the Protoaurignacian are illegible, against only $10 \%$ for the Early Aurignacian. Statistical analysis of the marks observed on the faunal remains identifies highly significant differences between both layers for all tested alterations except cracks (tab. 1). The bone surfaces are commonly abraded in the Protoaurignacian layer-which echoes observations of the lithic material (cf. supra)while those of the Early Aurignacian are frequently affected by root etching. Dissolution cupmarks and trampling scratches are more frequent in the assemblage attributed to the Protoaurignacian. Butchery cutmarks, percussion notches and burnt bones are common in both assemblages, particularly in the Early Aurignacian. Remains with evidences of carnivores gnawing are rare in both assemblages ( $1 \%$ or less); $28 \%$ of chewed remains come from the assemblage attributed to the Protoaurignacian and 33\% of those of the Early Aurignacian also exhibit butchery cutmarks.

Figure 3 - a) Length (in $\mathrm{mm}$ ) of the faunal remains uncovered at Les Abeilles and b) description of the marrow-bearing elements: length and shaft circumference relative to a complete element and type of fracture.

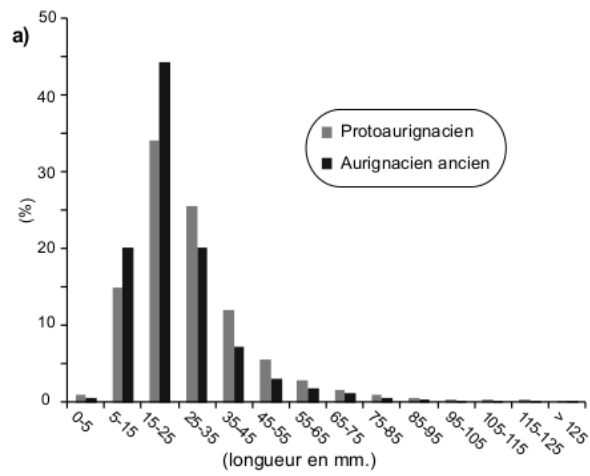

\begin{tabular}{|c|c|c|c|c|c|}
\hline & & \multicolumn{2}{|c|}{ Protoaurignacien } & \multicolumn{2}{|c|}{ Aurignacien ancien } \\
\hline & & NR & $\%$ & NR & $\%$ \\
\hline \multirow{5}{*}{ longueur } & 1 & 526 & 88,4 & 1132 & 84,2 \\
\hline & 2 & 46 & 7,7 & 133 & 9,9 \\
\hline & 3 & 11 & 1,8 & 59 & 4,4 \\
\hline & 4 & 8 & 1,3 & 11 & 0,8 \\
\hline & 5 & 4 & 0,7 & 9 & 0,7 \\
\hline \multirow{3}{*}{ circonférence } & 1 & 575 & 96,6 & 1288 & 95,8 \\
\hline & 2 & 9 & 1,5 & 22 & 1,6 \\
\hline & 3 & 11 & 1,8 & 34 & 2,5 \\
\hline \multirow{4}{*}{$\begin{array}{l}\text { Type de } \\
\text { fracture }\end{array}$} & frais & 296 & 78,9 & 1532 & 83,7 \\
\hline & $\mathrm{sec}$ & 66 & 17,6 & 105 & 5,7 \\
\hline & feu & 0 & 0,0 & 18 & 1,0 \\
\hline & récent & 13 & 3,5 & 175 & 9,6 \\
\hline
\end{tabular}

\section{2 - Faunal spectrum}

Both assemblages offer rich faunal spectra (tab. 2). The most common ungulates in the assemblage attributed to the Protoaurignacian are the Bovines, the Horse and, to a lesser extent, the Reindeer. The importance of large ungulates is increased when one takes into account the remains assigned to a size class. Carnivores are frequent, including the Bear and the Fox. In the assemblage attributed to the Early Aurignacian, the Reindeer is the most frequent species, before the Bovines and the Horse; the Fox is the best-represented carnivore, far ahead of the Bear and the Hyena. 
Table 1 - Number of Specimens, percentages and Chi2 test results for bone surface alterations in the Protoaurignacian and Early Aurignacian layers at Les Abeilles. *Percentages of fracture were calculated on marrow-bearing bones. Cutmarks percentages were calculated only using remains with an observable surface.

\begin{tabular}{lll|lc|cc} 
& \multicolumn{2}{c}{ Protoaurignacien } & \multicolumn{2}{c}{ Aurignacien ancien } & \multicolumn{1}{c}{ Chi ${ }^{2}$} & $p$ \\
& NR/NRt & $\%$ NRt & NR/NRt & $\%$ NRt & & \\
\hline Fissures longitudinales & $120 / 2561$ & 4,7 & $510 / 12281$ & 4,2 & 1,481 & $>0,05$ \\
Délitement & $32 / 2561$ & 1,2 & $63 / 12281$ & 0,5 & 18,076 & $<0,001$ \\
Dissolution & $127 / 2561$ & 5,0 & $153 / 12281$ & 1,2 & 157,851 & $<0,001$ \\
Lustré & $7 / 2561$ & 0,3 & $6 / 12281$ & 0,0 & 12,202 & $<0,001$ \\
Piétinement & $33 / 2561$ & 1,3 & $3 / 12281$ & 0,0 & 139,952 & $<0,001$ \\
Desquamation & $84 / 2561$ & 3,3 & $187 / 12281$ & 1,5 & 36,506 & $<0,001$ \\
Abrasion & $444 / 2561$ & 17,3 & $172 / 12281$ & 1,4 & 1352,87 & $<0,001$ \\
Corrosion & $29 / 2561$ & 1,1 & $15 / 12281$ & 0,1 & 73,167 & $<0,001$ \\
Concrétion & $17 / 2561$ & 0,7 & $228 / 12281$ & 1,9 & 18,569 & $<0,001$ \\
Vermiculations & $26 / 2561$ & 1,0 & $588 / 12281$ & 4,8 & 76,053 & $<0,001$ \\
Traces de dents & $26 / 2561$ & 1,0 & $21 / 12281$ & 0,2 & 47,846 & $<0,001$ \\
Os brûlés & $136 / 2561$ & 5,3 & $2922 / 12281$ & 23,8 & 442,509 & $<0,001$ \\
Indices de fracturation * * & $158 / 803$ & 19,7 & $536 / 1650$ & 32,5 & 43,678 & $<0,001$ \\
Stries* & $233 / 1033$ & 22,6 & $857 / 2687$ & 31,9 & 31,412 & $<0,001$
\end{tabular}

Table 2 - The faunal spectra at Les Abeilles: Number of Specimens (NR), \% of Number of Identified Specimens (\%NRd) and Minimum Number of Individuals (NMI). Abbreviation: "ind." = indeterminate.

\begin{tabular}{|c|c|c|c|c|c|c|}
\hline & \multicolumn{3}{|c|}{ Protoaurignacien } & \multicolumn{3}{|c|}{ Aurignacien ancien } \\
\hline & NR & $\%$ NRd & NMI os/dent & NR & $\%$ NRd & IMl os/dent \\
\hline Equus cabal/us & 93 & 18,1 & $3 / 5$ & 322 & 15,9 & $7 / 8$ \\
\hline Bovinae & 95 & 18,5 & $3 / 6$ & 411 & 20,3 & $6 / 10$ \\
\hline Rangifer tarandus & 81 & 15,8 & $3 / 4$ & 872 & 43,1 & $8 / 6$ \\
\hline Cervus elaphus & 21 & 4,1 & $2 / 2$ & 27 & 1,3 & $2 / 2$ \\
\hline Capra sp. & - & - & & 8 & 0,4 & $1 / 2$ \\
\hline Sus scrofa & 5 & 1 & $0 / 2$ & 2 & 0,1 & $a / 2$ \\
\hline Rupicapra rupicapra & 6 & 1,2 & $1 / 0$ & 17 & 0,8 & $2 / 2$ \\
\hline Equus hydruntinus & 2 & 0,4 & $1 / 1$ & 2 & 0,1 & $a / 1$ \\
\hline Megaloceros giganteus & 1 & 0,2 & $1 / 0$ & 4 & 0,2 & $1 / 0$ \\
\hline Mammuthus primigenius & 3 & 0,6 & $0 / 1$ & 10 & 0,5 & $0 / 1$ \\
\hline Vulpinae & 85 & 16,6 & $5 / 7$ & 223 & 11 & $5 / 7$ \\
\hline Ursidae & 94 & 18,3 & $1 / 9$ & 70 & 3,5 & $1 / 8$ \\
\hline Crocuta crocuta spelaea & 17 & 3,3 & $1 / 4$ & 29 & 1,4 & $1 / 7$ \\
\hline Felis silvestris & 5 & 1 & $1 / 1$ & 5 & 0,2 & $1 / 2$ \\
\hline Canis lupus & 5 & 1 & $1 / 1$ & 8 & 0,4 & $1 / 1$ \\
\hline Lynx sp. & - & - & & 1 & 0,05 & $1 / 0$ \\
\hline Mustélidés & - & - & & 3 & 0,1 & $1 / 1$ \\
\hline Lagomorphes & - & - & & 7 & 0,3 & $2 / 1$ \\
\hline Total dét. & 513 & & $23 / 43$ & 2021 & & $40 / 61$ \\
\hline Ongulés $1 / 2$ & - & & & 53 & & \\
\hline Ongulés 2 & 126 & & & 155 & & \\
\hline Ongulés $2 / 3$ & 179 & & & 90 & & \\
\hline Ongulés 3 & 7 & & & 1 & & \\
\hline Ongulés 3/4 & 315 & & & 731 & & \\
\hline Ongulés 4 & 132 & & & 8 & & \\
\hline Ongulés 4/5 & 1 & & & 2 & & \\
\hline Ongulés 5 & - & & & 1 & & \\
\hline Grands carnivores ind. & 9 & & & 8 & & \\
\hline Moyens carnivores ind. & - & & & 1 & & \\
\hline Carnivores ind. & 2 & & & 1 & & \\
\hline Mammifères ind. & 1277 & & & 9209 & & \\
\hline Total & 2561 & & & 12281 & & \\
\hline
\end{tabular}

\section{3 - Age, sex and hunting seasons (fig. 4)}

15 The dental remains collected in the assemblage attributed to the Protoaurignacian indicate that all age classes are present for the Reindeer, the Horse and the Bovines. 
Thanks to the canines (Barone 1986), we know that two male horses would be present in the assemblage attributed to the Protoaurignacian. Foetal bones indicate the presence of four mares; the dimensions of these bones indicate that they have been killed between early October and mid-December. A Reindeer foetus bone indicates the presence of a female whose death season would be between January and March. The use-wear of a deciduous tooth indicates the death of a young reindeer between August and November.

Mortality profiles of the layer attributed to the Early Aurignacian also indicate all age groups. The Bovines profile shows an overrepresentation of prime-adults compared to other classes. The dimensions of a foetus bone indicate the slaughter of a pregnant female bovine in December-January. A foal would have been killed between October and March. A mare would have been captured in November and another between January and March.

Figure 4 - a) Mortality profiles and b) seasonal data for Reindeer, Horse and Bovines at Les Abeilles.

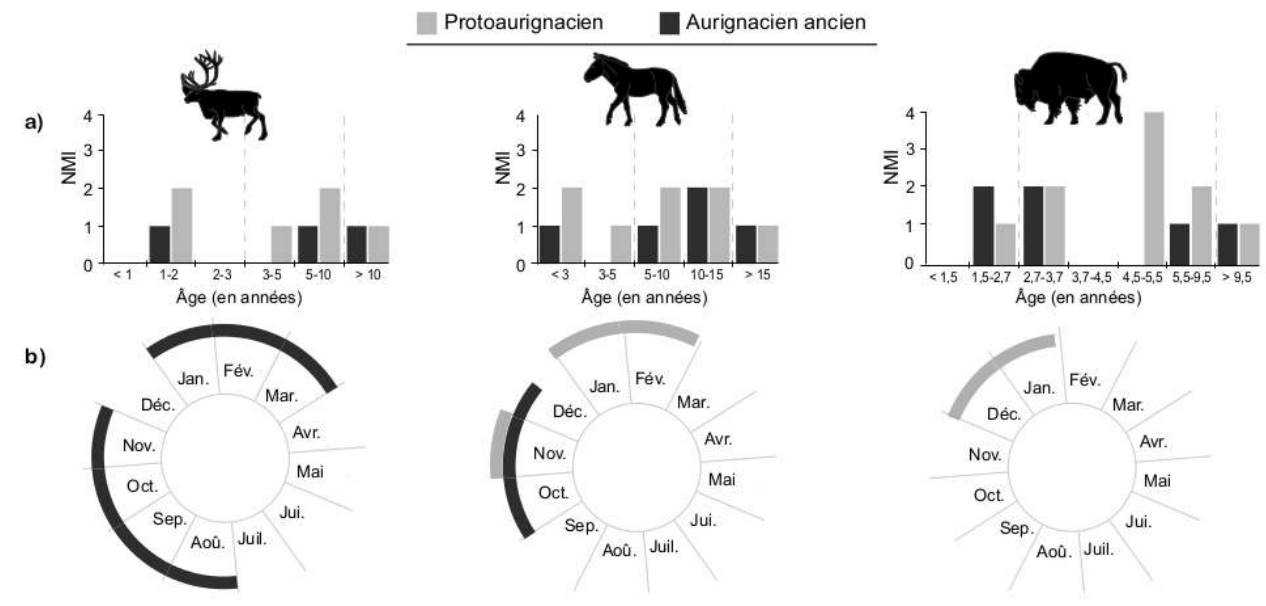

\section{4 - Skeletal representation}

For all taxa or techno-complexes, long bones and mandibles are the most common elements in the faunal assemblages (fig. 5a-b). The skull is found in varying proportions depending on taxa and appears more frequently in the assemblage attributed to the Protoaurignacian. For the Horse and the Bovines in both assemblages, metapodials are less common than the upper limb bones, while they are present in high quantity in the Reindeer skeletal profiles. The girdle bones are also less frequent for large ungulates than for the Reindeer. Axial skeleton elements and phalanges are neatly lacking in all species for both assemblages. The patella, carpal and tarsal bones are systematically under-represented despite the presence of the adjacent bones.

The confrontation of the various skeletal parts present at Les Abeilles with the density indices gives very low non-significant correlations (fig $5 \mathrm{c}$.); skeletal profiles do not appear correlated with the meat mass borne by the bones (fig. 5c). By contrast, very high correlations are observed with bone marrow indices (amount of marrow contained in the medullar cavity and total amount of unsaturated fats: fig 5c). Thus 
skeletal profiles do not seem to illustrate the presence of complete carcasses in the cave, but of carcass segments.

Figure 5 - Skeletal profiles in \%MAU for the a) Protoaurignacian and b) Early Aurignacian layers at Les Abeilles. c) Spearman correlations on element frequencies compared to their density value, the (S)FUI (Standardized Food Utility Index), marrow cavity volume, and the quantity of unsaturated fatty acids (UMI, Unsaturated Marrow Index). Statistically significant results (at the 0.05 level) are shown in bold.

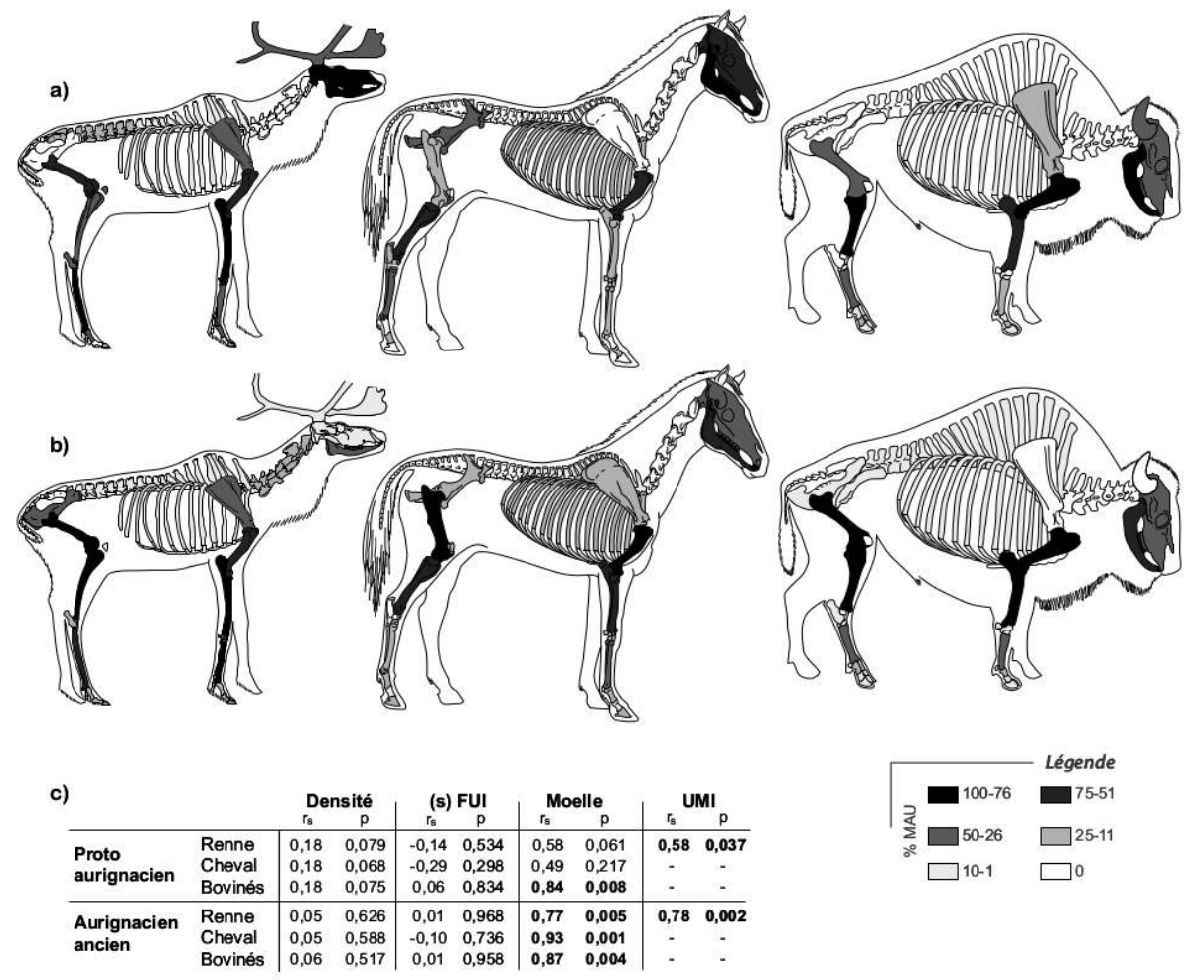

\section{5 - Butchery marks}

\subsection{1 - The butchery cutmarks (fig. 6)} They were found only on the ribs of large ungulates (Horse or Bovine) in the layer attributed to the Protoaurignacian and on the Reindeer and the Bovine in the Early Aurignacian. on the labial face of a Reindeer jugal tooth indicate an incision of the skin at the mouth. For that species, a longitudinal cutmark located in the posterior face of a first phalange gives evidence of an incision of the skin at the acropodium. For the Horse, cutmarks located on the teeth indicate the removal of the skin of at least one mandible and that of the skull of at least one foal and one adult. Two long cutmarks distally located on the metatarsal shaft could have been created by the removal of the skin. The dental remains and a mandible fragment of a Bovine testify that the skin of the mandible was 
removed on at least three individuals. A second phalange of Bovine bears transverse cutmarks on the abaxial face. The skinning of carnivores is also evidenced in the Protoaurignacian assemblage: the skin of the skull of at least two bears, one wolf, one cat and one hyena was removed. A distal portion of a Bear fibula carries a series of oblique cutmarks that may have been created during skinning (see Mallye 2011).

In the assemblage attributed to the Early Aurignacian, skinning marks are numerous on the remains of Reindeer; they have been observed on most of the elements that could potentially be affected by this operation. The removal of the skin of the skull and mandible is documented, but the majority of skinning evidences were observed on metapodial bones. On the metacarpal, two circular incisions are documented via transverse cutmarks located on the proximal and medial portions of the diaphysis. Oblique cutmarks reflect oblique gestures performed to detach the skin. On the metatarsal, transverse cutmarks continuing on the medial, posterior and lateral faces indicate a circular incision on the distal part of the diaphysis, while the longitudinal cutmarks on the medial face illustrate an upward gesture from the circular incision towards the ventral evisceration incision. Circular incisions are also documented on the first and second phalanges of this species. For the Horse, skinning cutmarks are present on the skull of a foal and on the mandible of at least three individuals including a young one. At the legs, a circular incision is documented on the mid-shaft portion of a metacarpal. Skinning cutmarks were also observed on the mandible of at least two Bovines. On the metapodial bones, circular incisions appear in the proximal part and oblique cutmarks related to the detachment of the skin are present over the entire length of the diaphysis. Transverse cutmarks on the distal shaft of the tibia could reflect a circular incision at the base of the meaty elements. For the Fox, the skinning cut marks testify to the removal of the skin of the skull of at least one cub and one adult, and of the mandible. Transverse cutmarks located on several first and second phalanges, as well as on metapodial bones, indicate an incision done at the bottom of the legs for at least two foxes. Finally, a jaw fragment confirms the skinning of a Wolf skull.

Defleshing cutmarks, short and almost exclusively transverse or oblique, are common in both assemblages.

For the three main ungulates of the assemblage attributed to the Protoaurignacian, they are found on all the long meaty bones, with the exception of the Reindeer tibia and the Bovine radius. They have also been identified on a Red deer humerus and a Fox tibia.

The removal of meat located on the ribs is confirmed for the Reindeer, the Horse and the Fox. The Reindeer scapula is the only part of the girdle to bear diagnostic defleshing cutmarks. The removal of the tongue is only demonstrated for the Bovines through cutmarks located on the lingual surface of jugal teeth.

In the assemblage attributed to the Early Aurignacian, defleshing cutmarks are present on the ribs of the Reindeer, the Horse, the Bovines and the Fox. Several fragments of thoracic and/or lumbar vertebras of Reindeer, Bovines and Ibex show cutmarks typically produced during the removal of the loin. In contrast, the defleshing of the neck and girdles is only documented for the Reindeer. All the long meaty bones of Reindeer, Horse and Bovines bear defleshing cutmarks. The limb bones of at least three foxes also have this type of cutmarks. For other species, defleshing cutmarks are rare; they have nevertheless been observed on the humerus, radius and tibia of a red deer, 
the radius of a megaloceros and of an izard and on the femur and tibia of a hare. Finally, cutmarks located on the lingual face of a Reindeer mandible fragment indicate the removal of the tongue.

Articular extremities are scarce in both assemblages, which greatly limits the possibilities to observe disarticulation cutmarks. In relation to the tNSP of each assemblage, articular extremities-the most susceptible parts for this type of cutmarks -are slightly more frequent in the assemblage attributed to the Protoaurignacian (4.41\% of the tNSP) than in the Early Aurignacian (3.13\% of the tNSP). The dismemberment cutmarks are nevertheless more abundant in the layer attributed to the Early Aurignacian.

In the assemblage attributed to the Protoaurignacian, evidences of a disarticulation of the mandible and the skull were only observed on Bovine. However, disarticulation cutmarks are visible on the long bones of the Bovines and the Horse and on phalanges for the Reindeer. The postcranial axial skeleton of ungulates shows no disarticulation cutmarks. A deep incision on the cranial part of a Fox caudal vertebra points out that the tail was disarticulated from the axial skeleton for this species.

No disarticulation mark was observed in the head in the assemblage attributed to the Early Aurignacian. Several cutmarks, located in the ribs and vertebrae, document the separation of the spine and ribs. Deep cutmarks located in the distal portion of the ribs indicate that they were dissociated from the sternum for the Horse, the Reindeer and the Bovine. In contrast with Reindeer and Horse, none of the limb bones of Bovine show dismemberment marks. Disarticulation cutmarks between the pelvis and the femur were observed on a Fox femoral head. Deep cutmarks located on the calcaneus indicate a disarticulation performed on the tarsal block for the Hare and the Ibex.

The severing of tendons is shown in both assemblages by short and transverse cutmarks located on the grooves of the metapodials. In the Protoaurignacian assemblage, these cutmarks are present on the metacarpals and metatarsal of the Reindeer, the Bovines and the Red deer. For the Early Aurignacian assemblage, the removal of the flexor and extensor tendons was carried out on the Reindeer, the Bovines, the Horse and the Red deer. 
Figure 6 - Summary of the different types of cutmarks observed on Reindeer, Horse and Bovines at Les Abeilles.

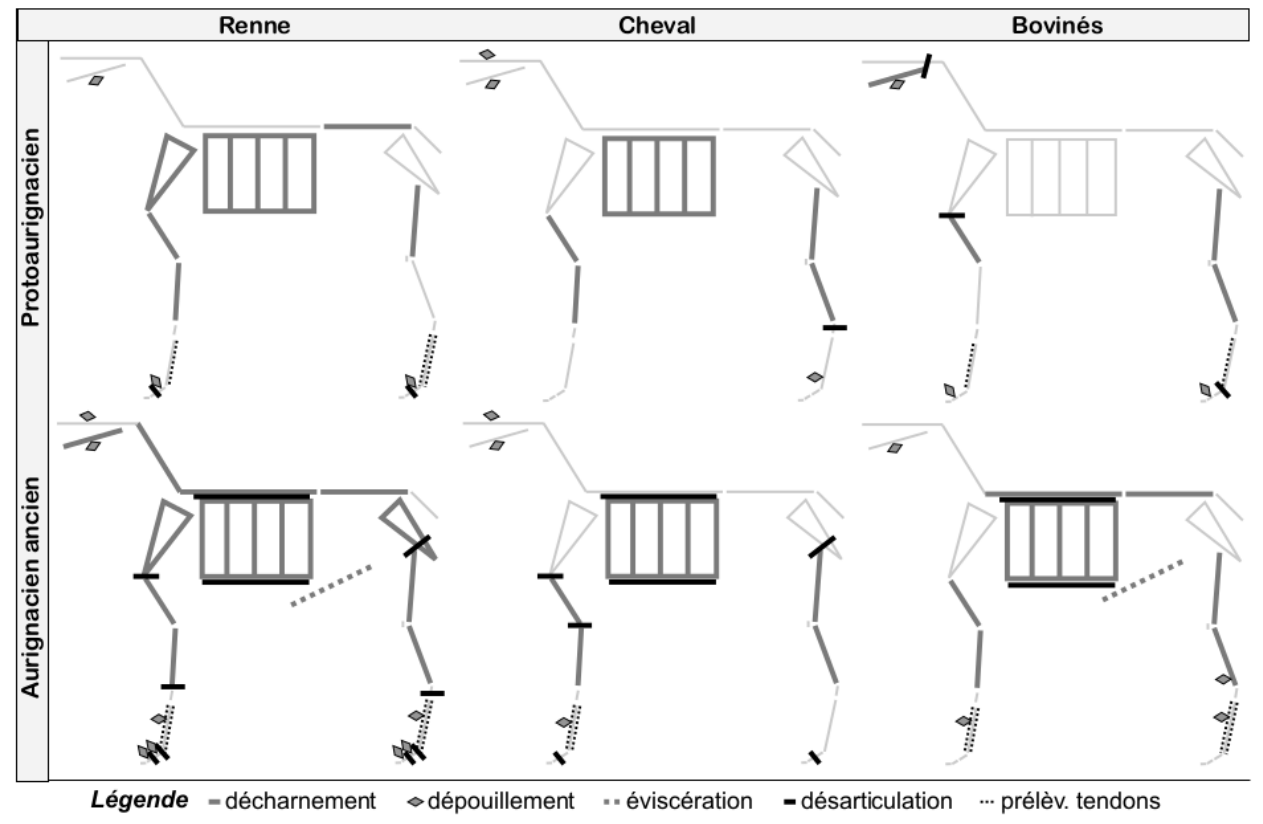

\subsection{2 - Bone fracturing Indices} are present on $32.5 \%$ of the bones with marrow cavity and were observed on Reindeer, Horse, Bovine, Red deer, Izard and, with a greater degree of uncertainty, on Fox remains. They are mainly located on the long bones diaphysis but were also observed on four fragments of Reindeer mandibles and four of Bovine. No notch was observed on the Horse mandible fragments but twelve lower jugal teeth $(\mathrm{MNI}=5)$ have an oblique split shaft that could have been broken during the fracturing of the mandible (e.g. Morel and Müller 1997; Costamagno 1999; Outram 2005). Several upper jugal teeth also have oblique split shafts that can indicate the opening of a horse head. Four first phalanges and five second phalanges (Reindeer and Bovines) show percussion notches. 
Nine bone fragments bear impacts and counter-impacts, documenting the use of an anvil. Alignments of percussion notches were observed on twelve diaphysis fragments (fig. 7). These objects almost always show a retoucher area; these alignments of notches could well demonstrate a debitage aimed at controlling the morphology of the blank. A percussive impact has been identified on a humeral head of Reindeer and several percussion notches are located in close proximity to the articular extremities of long bones. Three bones of the carpal and tarsal blocks have very straight and smooth fracture edges suggesting the intentional nature of their fracturing (see Darwent and Lyman 2002). This breakage, however, was not systematic since half of the short bones were collected whole (13 out of 24). Indeterminate spongy elements under $25 \mathrm{~mm}$ make $26 \%$ of the tNSP. In this sample, $60 \%$ of the remains do not show any trace of heating.

\section{6 - The burnt bones}

The presence of burnt bones was noted in both assemblages; this type of material is more abundant in the layer attributed to the Early Aurignacian ( $23.8 \%$ of the tNSP) than in the Protoaurignacian (5.3\% of the tNSP).

The vast majority of the burnt objects collected in the assemblage attributed to the Protoaurignacian are at least charred (tab. 3) and small in dimensions since $93.4 \%$ of them are less than $2 \mathrm{~cm}$ long. This burnt material is composed at $69 \%$ of compact structure, $28 \%$ of spongy elements, $2 \%$ of dental remains and $1 \%$ of axial skeleton. The rate of burnt bone with spongy structure seems too low to interpret their presence as resulting from the use of the bone material as fuel. Nevertheless, the lack of specific information on the use of sieving does not allow knowing whether the small fragments of charred spongy bone were collected exhaustively. In this assemblage, an ungulate rib fragment of large size has a distal burn that indicates the roasting of a piece of rib cage. Light scorch marks were observed on the occlusal surface of three Reindeer teeth. Because of their location, they could indicate that a head-the jaw being previously dismantled- was directly deposited in a hearth, for brain cooking.

In the assemblage attributed to the Early Aurignacian, almost all the remains correspond to compact or spongy tissue (respectively $51 \%$ and $46 \%$ of the burnt pieces), with very low occurrences of axial skeleton, skull fragments and dental remains. This burnt material is highly fragmented $(92.8 \%$ of the objects are under $2 \mathrm{~cm})$ and essentially corresponds to at least charred bones (tab. 3). These data are consistent with a use of the bone as fuel material. The burnt pieces that could be determined mainly belong to the Reindeer and to spongiosa-rich elements (articular extremities, short bones, girdles: see Soulier 2013). The work to determine these burnt pieces has especially highlighted that the carpal and tarsal bones of Reindeer are "frequently" burnt (28.6\% of the carpal NISP and $33.3 \%$ of the tarsal NISP) which could explain the underrepresentation of these elements in the skeletal profile (see fig. 5). Lastly, a Horse rib head and a shaft fragment of medium-size ungulate long bone show distal burns indicating the consumption of meat roasted on bone. 
Table 3 - Characterization of the burned remains uncovered in the Protoaurignacian and Early Aurignacian layers at Les Abeilles with values calculated as a function of the Number of Specimens and the percentage of burned bones. Combustion stages are as in Costamagno et al. 2009.

\begin{tabular}{|c|c|c|c|c|}
\hline & \multicolumn{2}{|c|}{ Protoaurignacien } & \multicolumn{2}{|c|}{ Aurignacien ancien } \\
\hline & NR & \% d'os brûlés & NR & \% d'os brûlés \\
\hline \multirow{4}{*}{ 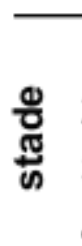 } & 12 & 8,8 & 12 & 0,4 \\
\hline & 112 & 82,4 & 2778 & 95,1 \\
\hline & 12 & 8,8 & 27 & 0,9 \\
\hline & 0 & 0 & 105 & 3,6 \\
\hline
\end{tabular}

Figure 7 - Example of a bone fragment with aligned percussion notches (black dots). In light grey: the fragment; dark grey square: area used as retoucher, thick black line: scrape marks.

\begin{tabular}{|c|c|c|c|c|}
\hline & \multicolumn{2}{|c|}{ Protoaurignacien } & \multicolumn{2}{|c|}{ Aurignacien ancien } \\
\hline & NR & \% d'os brûlés & NR & \% d'os brûlés \\
\hline 1 & 12 & 8,8 & 12 & 0,4 \\
\hline 음 2 & 112 & 82,4 & 2778 & 95,1 \\
\hline 跔 3 & 12 & 8,8 & 27 & 0,9 \\
\hline 4 & 0 & 0 & 105 & 3,6 \\
\hline
\end{tabular}

\section{7 - The hard animal matter industry}

The presence of industry in hard animal matter is evidenced in both assemblages. Compared with the first inventory of bone tools and ornament at Les Abeilles (Barandiarán 2006), resuming the faunal study led to the isolation of many additional pieces that considerably increased the corpus ${ }^{4}$.

Only six pieces were originally described for the layer attributed to the Protoaurignacian (op. cit.). This corpus has been significantly increased with thirteen retouchers and one intermediate tool (fig. 8a). However, the previously described smoothers appear to be more likely highly blunt pieces, as well as the pendant, on which a dissolution cup mark was mistaken for a perforation. The species used as blanks for making this industry are the Bovines, the Horse, the Reindeer, the Red deer and the Mammoth, plus a few pieces from large ungulates and indeterminate deer. The majority of this industry is made on bone and corresponds to retouchers. An intermediate tool on large ungulate bone, a spear point on antler and two ivory rods complete the series. The length of the flakes selected as retoucher blanks varies between 35 and $125 \mathrm{~mm}$ (fig. 8b); five of them show an adjustment of the surface by scraping to remove the periosteum. Because of the small number of remains, it is not possible to perceive any preferentially used part for the retouching area; we can simply point out that the middle of the posterior diaphysis of the humerus was used in both the Red deer and the Bovines. 
40 For the assemblage attributed to the Early Aurignacian, the corpus of faunal remains processed for utilitarian or symbolic purposes (fig. 9a) consists of 148 elements (plus potentially 7 more) against only 48 described before. This industry was mostly made from Bovines (fig. 9a and tab. 4) and, to a lesser extent, from Reindeer, Horse, Red deer, Mammoth, Fox and Bear.

41 The long bones were used as blanks for the manufacturing of more than $70 \%$ of the industry. Fragments of Reindeer and Bovine mandible, vestigial metapodials, large ungulates ribs, antler, carnivore teeth and Mammoth ivory have more rarely been used to make smoothers, awls, spears points, ornamental elements, etc. However, this industry consists predominantly of retouchers, whose blanks are generally between 55 and $85 \mathrm{~mm}$ long (fig. 9b). One third of the retouchers show a modification of the bone surface by scraping, generally performed longitudinally to the axis of the bone. Fourteen retouchers have a double area and another has three. These multiple retouchers were mainly observed on femur (33\% of the tNSP of multiple retouchers) and exclusively on large ungulate bones: nine on Bovine (including the triple retoucher) and five on Horse.

A recurrence in the location of the retouching areas can be perceived. Five out of the eight retouching areas observed on the radio-ulna of Bovine are located in the middle of the anterior diaphysis (fig.10a) and, for the femur, six of the twelve areas are located in the distal third of the lateral diaphysis (fig.10b). These recurrences are essentially visible by taxon and may be directly linked to specific bone properties of each species (degree of concavity/convexity, thickness and texture of the diaphysis, etc.). However, a recurrence in the mid-diaphysis of the humerus, on the lateral side, appears for the Bovine, the Horse and the Reindeer (fig.10c). The presence of aligned percussion notches on seven retouchers could suggest a controlled debitage of some blanks.

Figure 8 - a) List of the worked faunal remains and b) lengths of the retoucher blanks recovered in the Early Aurignacien layer at les Abeilles.

a)

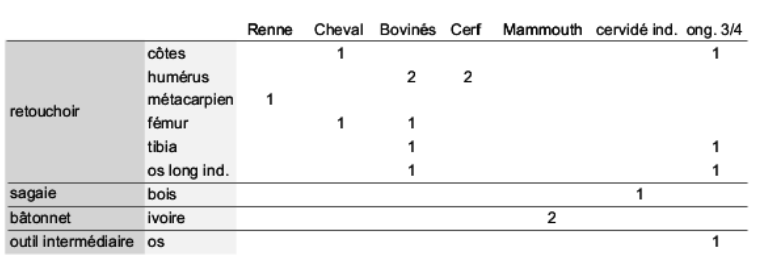

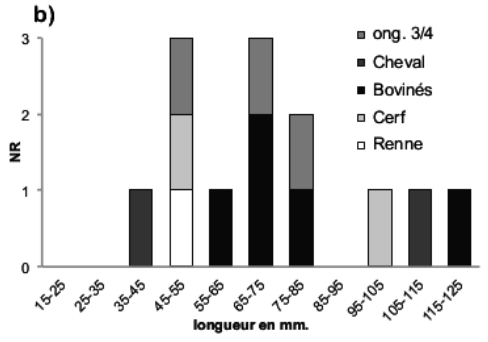

Table 4 - Chi2 test results for the number of remains used as retouchers in the Early Aurignacian layer at Les Abeilles (Bovines, Reindeer, Horse). Results were compared to the total NISP for a given species.

\begin{tabular}{ll|ll} 
& & \multicolumn{1}{|c}{ Chi $^{\mathbf{2}}$} & \multicolumn{1}{c}{$\mathbf{p}$} \\
\hline Renne & Bovinés & 37,0355 & $1,16 \mathrm{E}-09$ \\
Bovinés & Cheval & 10,1027 & 0,001481 \\
Cheval & Renne & 2,3308 & 0,1268
\end{tabular}


Figure 9 - a) List of the worked faunal remains and b) lengths of the retoucher blanks recovered in the Early Aurignacien layer at les Abeilles.

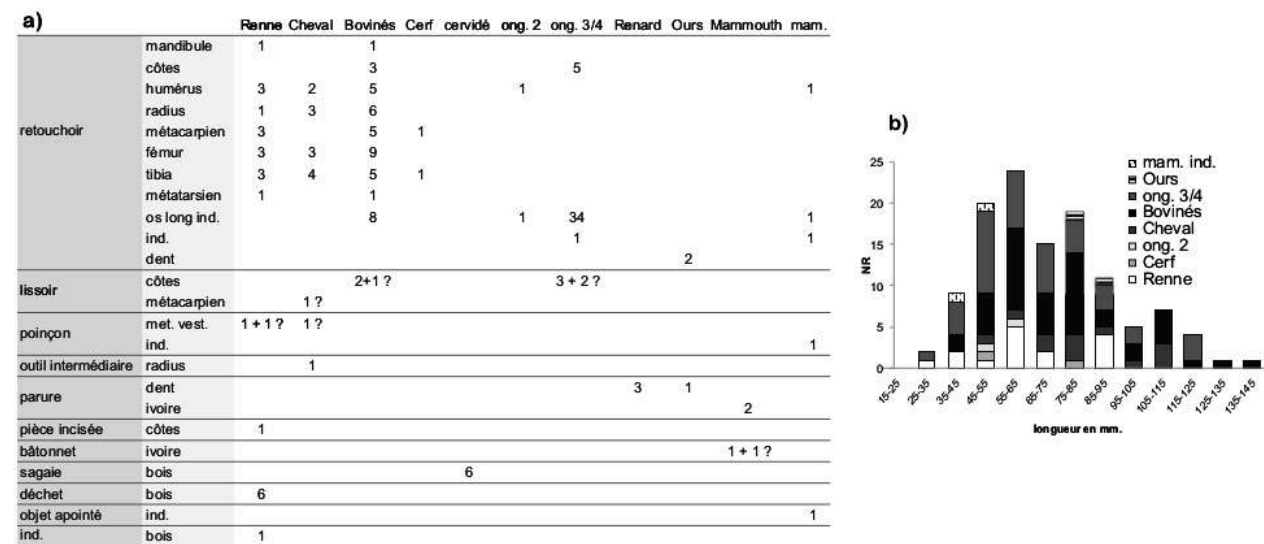

Figure 10 - Patterns in retoucher surface areas in the Les Abeilles Early Aurignacian assemblage on a) Bovine radio-ulna, b) Bovine femur and c) Bovine, Horse and Reindeer humerus.
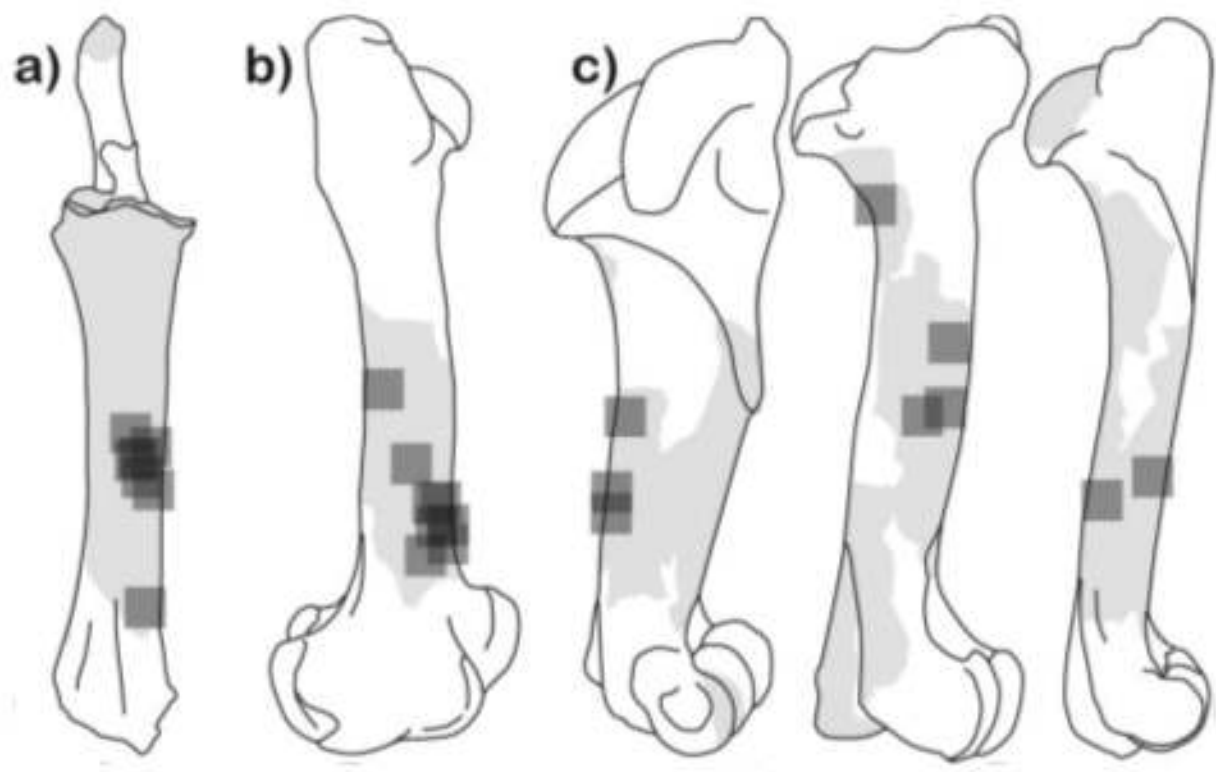

\section{5 - Discussion}

The new archaeozoological data obtained for the assemblages attributed to the Protoaurignacian and Early Aurignacian in Les Abeilles provide discussion elements about the faunal exploitation strategies during the early Upper Palaeolithic. In addition to food exploitation, part of the fauna was used as blank for industry and ornaments. Thus, the combined analysis of all faunal remains allows reconstructing the sequence of exploitation of the fauna and understanding the degree of overlap between the dietary, technical and symbolic spheres. 


\section{1 - Faunal spectrum and accumulation agent}

Although broadly similar, the faunal spectra differ in terms of abundance of species. The faunal spectrum is dominated by the Bovine-Horse-Reindeer trio in the Protoaurignacian, while in the Early Aurignacian the Reindeer increases at the expense of the Horse and the Bovines. This increase of the Reindeer might result from a stronger presence of this species in the environment (Grayson, Delpech, Rigaud 2001, Grayson and Delpech, 2002, 2006; Morin, 2008, 2012; Discamps 2011; Discamps et al. 2011) rather than from a more pronounced attraction of this species for the Early Aurignacian hunters of Les Abeilles.

If the Bear and the Fox are important in the faunal spectra, these two species do not seem to be the main accumulators of the bone stocks due to their diet (see Bocherens, Fizet, Mariotti 1990, Larivière and Pasitschniak-Arts 1996). The Hyena is barely present in both assemblages and gnawing marks are rare and well below the rate from hyena dens, including recently excavated ones (e.g. Villa et al. 2004; Beauval and Morin 2010; Discamps 2011). Several gnawed pieces also bear butchery cutmarks, arguing in favour of bone stocks accumulated by Man, on which carnivores intervened marginally.

\section{2 - Food exploitation of prey}

Food exploitation is documented in both assemblages for the Reindeer, the Horse, the Bovines, the Red deer and the Fox. The range of species exploited for food is larger in the assemblage attributed to the Early Aurignacian, since the Ibex, the Izard, the Megaloceros and the Hare can be added to these species. As the cutmarks are epiphenomena, we cannot exclude that the absence of food exploitation evidences is not simply related to the sample size since the NS of these species is lower in the assemblage attributed to the Protoaurignacian than in the Early Aurignacian. very young bovines and reindeers seem to have been avoided. On the other hand, the hunters seem to have preferentially targeted prime-adults bovines in the Early Aurignacian. Seasonal data indicate a recurrence in the period of occupation of the site between both assemblages, in the autumn and winter. Considering the sex of the preys, these seasons indicate the exploitation of interesting preys in terms of meat and fat. During the autumn, preys are in good health condition and, for the Reindeer and the Bovine hunted in winter, the females are in better physical condition than the males (Soper 1941; Kelsall 1968).

Skeletal profiles are relatively homogeneous between both assemblages, indicating that the preys were essentially transported to the cave as quarters rather as complete carcasses. The hunters preferentially transported marrow-rich elements at the expense of the axial skeleton, regardless of the species. The degree of selection of the carried parts seems correlated with the size of the prey; the limbs appear relatively complete for the Reindeer while the girdles and the lower legs bones are much less frequent than long meaty bones for large ungulates. Regarding the good physical condition of the slaughtered preys, carrying these heavy parts with respect to their limited nutritional value may explain their abandonment. Moreover, many ethnographic studies indicate that roasting rib grills and consuming marrow from metapodial bones commonly occur on kill sites (e.g. Binford 1978; Bunn, Bartram, Kroll 1988; Kent 1993). Several foetuses 
were identified in both assemblages; five foetuses are evidenced in the layer attributed to the Protoaurignacian (NS $=16$ ) and three are documented in the assemblage attributed to the Early Aurignacian (NS = 14). These foetuses were at a relatively advanced stage of development and are mostly of large ungulates. According to the transport strategies (cf. supra), these foetuses were deliberately brought into the cave by the hunters.

All the key-steps of the butchery process are documented in both assemblages: evisceration, skinning, defleshing, disarticulation, tendons and marrow extraction.

Defleshing is the activity that has produced most of the marks observed on the bone material. In both assemblages, the muscles were removed from most of the meaty elements and the tongue was retrieved. Defleshing has been done on the Reindeer, the Horse, the Bovines, the Red deer and the Fox in both assemblages, plus on the Ibex, the Izard, the Megaloceros and the Hare in the layer attributed to the Early Aurignacian. In both assemblages, some distal burns located on ribs and long bones indicate that some pieces of meat were roasted without prior boning. No cutmarks enables to certify that the foetuses' meat was removed; nevertheless, this meat is very tender and highly appreciated in many sub-actual human groups (e.g. Jenness 1923; Speck 1935; Burch 1972; Hungry Wolf 1980; Ingstad 1992; Houston S, Ball, Houston M. 2003).

51 Dismembering the carcasses to pieces using sharp tools is more documented in the assemblage attributed to the Early Aurignacian. However, one cannot exclude the use of a disarticulation by percussion in the assemblage attributed to the Protoaurignacian as some percussion notches are located near the articular extremities. Some butchery practices, such as making biltong, require no-or little-disarticulation (e.g. Nilssen 2000). However, if one wishes to recover the marrow contained in the medullar cavity of the bones, taking the limbs to pieces facilitates the breakage (e.g. Jin and Mills 2011).

Fracturing bones with medullar cavity to extract the marrow is documented in both assemblages. The species concerned by this activity are the Reindeer, the Bovines, the Horse, the Red deer and possibly the Fox in both assemblages, plus the Izard in the layer attributed to the Early Aurignacian. This operation was carried out on all the marrow-bearing elements: long bones, phalanges and mandible. However, bone marrow recovery has not been conducted exhaustively in both assemblages since some phalanges were recovered whole. These elements being the last providers of marrow in ungulates in case of undernutrition (Speth 1983; Morin 2007), this observation supports the idea of the exploitation of individuals in good physical condition in both assemblages. In the layer attributed to the Early Aurignacian, fracturing could also have been conducted on the skull to recover the brain. In both assemblages, large ungulates, and the Bovines in particular, are the ones with the greatest number of percussion notches. This observation can be correlated with the legibility of the percussion notches, directly related to the thickness of the cortical of the bones: the thicker the cortical, the more the notches are marked (Marean and Cleghorn 2003). Percussion notches are much more abundant in the assemblage attributed to the Early Aurignacian. This increase in the rate of notches is clearly visible on the Horse, with a percentage twice as high as in the Protoaurignacian. Complete marrow-bearing bones are however equally scarce in both assemblages, which does not allow supposing the recovery of the marrow was less important in the Protoaurignacian assemblage. The greater presence of percussion marks could instead result from the fracturing method used by the butchers. The use of an anvil is evidenced in the layer attributed to the 
Early Aurignacian and one wonders if this technique does not generate a greater visibility of the percussion marks. Several elements that can indicate a recovery of the fat contained in the spongy tissues (e.g. Leechman 1951; Lupo and Schmitt 1997; Outram 2001, 2002, 2005; Church and Lyman 2003; Saint-Germain 2005) were observed, particularly in the assemblage attributed to the Early Aurignacian: unburnt spongy fragments of small size, split short bones, percussion on joints extremities. Nevertheless, the fat processing is still too delicate to perceive to be able to state that this practice took place at Les Abeilles.

Figure 11 - Unfinished basked-shaped bead from the Early Aurignacian assemblage of Les Abeilles (c) Musée National de Préhistoire.

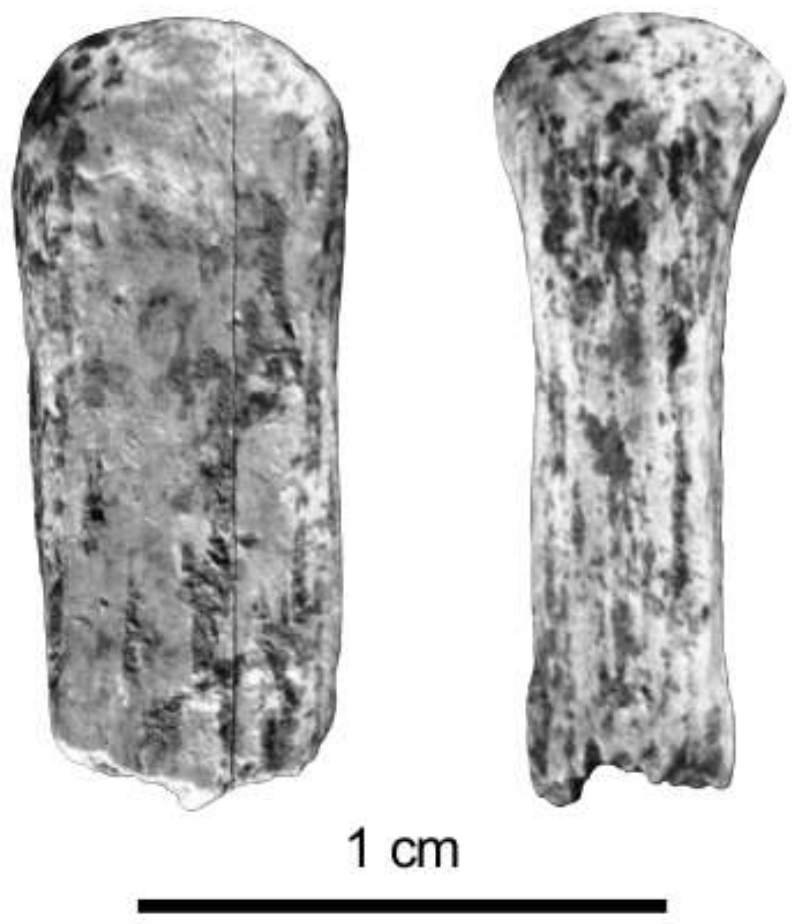

Figure 12 - Status of the exploited species in the Aurignacian layers at les Abeilles. Abbreviations: alim. = food; utilit. = utilitarian.
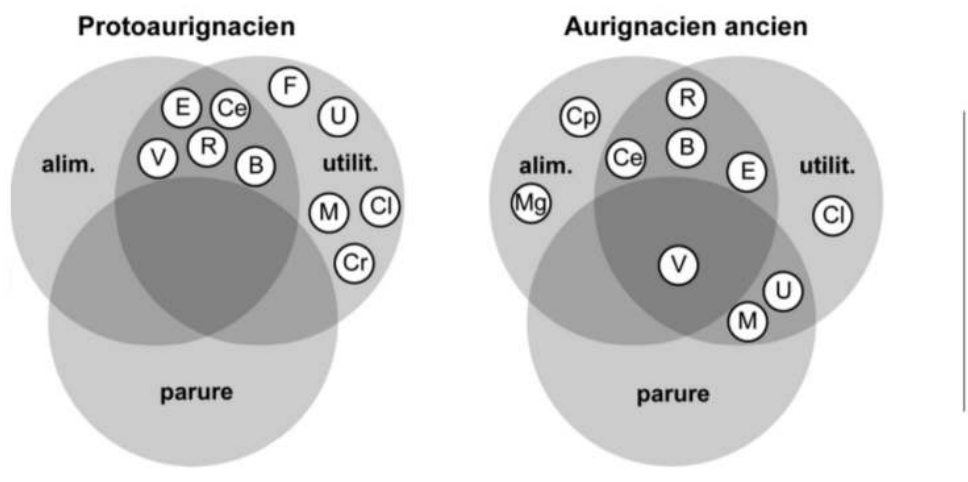

Légende :

E: Cheval, B: Bovinés,

R: Renne, Cp: Isard,

Ce: Cerf, Mg: Mégacéros

M: Mammouth, U: Ours,

V: Renard, Cl: Loup,

Cr: Hyène, F: Chat 


\section{3 - Technical exploitation of the fauna}

53 A wide range of species was used as industry and ornament blanks. The Reindeer, the Bovines, the Horse, the Red deer and the Mammoth were used in both assemblageS. To this list, the B and the Fox can be added in the layer attributed to the Early Aurignacian. As the flesh of the majority of these species was collected, an acquisition through hunting-and resulting from food activities-can be put forward. Only the Bear and the Mammoth are not included in this scheme. Bear remains are abundant in the cave and the presence of several deciduous teeth (with some lost ones) reflects the use of part of Les Abeilles cave as a den. The exploited Bear teeth could therefore easily have been harvested in situ. In the faunal spectrum, the presence of the Mammoth is only attested through ivory fragments. As fresh ivory is very difficult to work (White 1997), its presence at Les Abeilles could result from a supplying totally distinct from the food sphere. For industry elements made of antler, the lack of antler bases does not allow to specify whether the raw material used potentially comes from an acquisition in connection with the eaten preys (massacre antler) or if it was acquired in parallel, by collecting.

In both assemblages, skeletal elements used as blanks correspond to long bone diaphysis fragments of Bovines, Horse, Reindeer and Red deer and therefore could have been directly taken from the butchery waste available. However, their recovery was not done randomly as the blanks used have large dimensions in comparison with the average of the corpus in both assemblages. Observing multiple and aligned percussion notches on several retouchers of the layer attributed to the Early Aurignacian could also indicate that some blanks were selected before recovering the bone marrow. Multiple retouchers are also only confirmed in the assemblage attributed to the Early Aurignacian. A selection was also carried on species criterion in both assemblages, with a predilection for the Bovines, as observed in other Early Upper Palaeolithic series (Soulier 2013). This preference is clearly noticeable in the layer attributed to the Early Aurignacian.

Similarly to what has been described for other series of the Early Aurignacian (Castel and Madelaine 2003; Castel, Chauvière, Madelaine 2003; Tartar 2009), two Bear canines were used as retoucher blanks. On the other hand, although several Bear canines were collected in the assemblage attributed to the Protoaurignacian, none has been used to this effect. But retouchers on Bear canine exist in other series belonging to this technocomplex (Soulier, 2013; Soulier et al. 2014). The diversification of the skeletal elements exploited in the Early Aurignacian also concerned the mandible, the radio-ulna and the metatarsal. In both assemblages, the ribs of large ungulates were used to make retouchers and, in the Early Aurignacian, smoothers. Ribs are nevertheless very infrequent in the collected bone corpus; it can be assumed that they were occasionally preferentially transported from the kill-site, for the technical exploitation of the blanks.

The transformed objects also confirm that more diverse activities took place in the layer attributed to the Early Aurignacian than in the Protoaurignacian. In both assemblages, the presence of retouchers and intermediate objects respectively indicate the retouching/making of stone tools and splitting activities. As the blanks used are from the most abundant elements in both assemblages, their manufacture could have taken place at Les Abeilles. On the other hand, if hunting activities are directly attested 
by the presence of spear points in both assemblages, only the Early Aurignacian layer yielded waste indicating the manufacture of at least part of this armament in the cave. Ornaments items were only collected in the assemblage attributed to the Early Aurignacian; the discovery of an unfinished basket bead among the faunal remains (fig. 11) confirms the production of part of the ornaments in the cave.

The presence of smoothers and awls-making direct reference to the preparation of hides-is only attested in the assemblage attributed to the Early Aurignacian. The hunting seasons identified for the Reindeer, the Horse and the Bovines correspond to periods of high-quality skin (e.g. Ekblaw 1928; Soper 1941; Burch 1972; Binford 1978; Duncan 1992) and the analysis of cutmarks on the faunal remains interestingly echoes to this activity. The skinning cutmarks are indeed numerous in both assemblages. In the assemblage attributed to the Early Aurignacian, circular skin incisions are just as well located at the level of the acropodium as in the middle of the limb. This heterogeneity may indicate that the groups that have occupied Les Abeilles during the Early Aurignacian may not have had the same interest in the skin (e.g. Wheat, Malde, Leopold 1972; Binford 1981; Grønnow, Meldgaard, Nielsen 1983). Nevertheless, the identification of medial longitudinal incisions in the metapodial bones indicates a desire to recover skins of large dimensions. Moreover, the multiplication of the circular skin incisions could indicate a delayed skin removal of lower legs, as practiced by many groups living in cold environment (e.g. Burch 1972; Binford 1981; Grønnow et al, 1983; Russell 1995). In the layer attributed to the Protoaurignacian, skinning was performed on a varied range of species, including many carnivores. The location of the circular incisions, at the distal ends of the legs, reflects the removal of the skins in their maximum dimensions. The transport of foetuses may also have been done to this aim; their thin skin is indeed particularly prized by many groups of sub-actual huntergatherers (Curtis, 1930; Speck 1935 Blair 1966; Binford 1978, 1980, 1981; Speth 1983; Russell 1995; Nilssen 2000; Parget 2004; Peck 2004; Pinson 2004). No tool clearly dedicated to skin processing has been recovered in this Protoaurignacian assemblage but we cannot exclude subsequent treatment in another place or with tools that were not preserved. Tendons were also recovered in both assemblages. If the skin and tendons can be consumed (e.g. Holston 1963; Burch 1972; Stopp 2000; Stefansson 2004; Costamagno and David 2009), their most common use is utilitarian (e.g. Fleming and Theodora 1979; Binford 1981; Russell 1995; Pasda 2013).

The last technical utilization of fauna documented at Les Abeilles is the use of bone matter as fuel. According to the criteria proposed by Costamagno and colleagues (2009), the frequency, size and degree of burning of spongy elements evidence this practice in the layer attributed to the Early Aurignacian. Although burnt bones are present in the assemblage attributed to the Protoaurignacian, all the criteria are not gathered to be able to propose a use of the fat contained in the spongy tissues as fuel in this layer.

In sum, the confrontation of data from both assemblages shows as many similarities as differences. The exploited preys are of optimal quality in both assemblages and the transportation choices adopted are relatively similar. The number of species exploited for food seems more important in the layer attributed to the Early Aurignacian. In both assemblages, butchery cutmarks and percussion evidences indicate that the food was almost entirely recovered. However, the modes of disarticulation and the marrow recovery techniques seem to have differed between the two techno-complexes. Alongside food exploitation, a use of fauna for technical purposes is documented in 
both assemblages, with a use of antler and bones for making hunting weapons and domestic tools. An anticipation of this technical exploitation of fauna could have affected the prey capture seasons since many elements show activities oriented around skin working. In terms of overlapping between the technical sphere and food exploitation, major differences appear between the two assemblages. The fauna collected in the layer attributed to the Protoaurignacian suggests a less pronounced integration of the technical exploitation of fauna in the food activities: several species are only used for technical purposes, while species usually incorporate different spheres of activity in the assemblage attributed to the Early Aurignacian (fig. 12). The technical sequence of exploitation seems to have interacted more with the food exploitation of preys in the Early Aurignacian layer, in the sense that it appears to have dictated certain choices at the time of deciding of the elements transported into the cave and during butchery activities. On the other hand, the assemblage attributed to the Protoaurignacian shows that the skin has been recovered on a broader spectrum of species, including carnivore; a distinctive interest in foetuses was also observed in this assemblage. In both assemblages, the technical exploitation of the animal matter appears nonetheless closely related to the food area.

\section{6 - Conclusion}

The Aurignacian occupations at Les Abeilles have both yielded abundant faunal remains and their study documents many aspects of faunal exploitation by the people who occupied the site in the Early Upper Palaeolithic. The integration of the transformed faunal remains to the archaeozoological study showed that prey exploitation is complex in both assemblages and meets both dietary and technical needs

Differences are documented between the assemblages but it is difficult to know whether the "gaps" observed in the assemblage attributed to the Protoaurignacian compared to the Early Aurignacian are real or if they are artificially created by the sample size and the less well preserved faunal remains of the assemblage attributed to the Protoaurignacian. At Isturitz, the assemblage attributed to the Protoaurignacian confirms an overlapping of these different spheres equally pronounced as in the Early Aurignacian described here at Les Abeilles (Soulier, 2013; Soulier et al. 2014). Therefore, these differences cannot be seen as proof of less developed abilities-whatever they are -of the Protoaurignacian people with regard to those of the early Aurignacian, but would rather reflect a diversity of answers of these Early Upper Palaeolithic human groups facing different needs and/or constraints. 


\section{BIBLIOGRAPHY}

ALTUNA J. 2006 - Faune de mammifères de la grotte préhistorique des Abeilles, Haute Garonne. In : LAPLACE G. et al. (eds.), Les Aurignaciens pyrénéens des Abeilles et méditerranéen de Régismont-leHaut. Analyses typologique et paléontologique. Les Eyzies-de-Tayac: SAMRA, p. 142-153.

BACHELLERIE F. 2011 - Quelle unité pour le Châtelperronien? Apport de l'analyse taphonomique et techno-économique des industries lithiques de trois gisements aquitains de plein-air : le Basté (PyrénéesAtlantiques), Bidart (Pyrénées-Atlantiques) et Canaule II (Dordogne). Thèse de doctorat, Université Bordeaux I, 441p.

BARANDIARÁN I. 2006 - L'outillage aurignacien en os, bois de cervidé et ivoire de la grotte des Abeilles. In : LAPLACE G. et al. (eds.), Les Aurignaciens pyrénéens des Abeilles et méditerranéen de Régismont-le-Haut. Analyses typologique et paléontologique. Les Eyzies-de-Tayac: SAMRA, p. 112-123.

BARONE R. 1986 - Anatomie comparée des mammiferes domestiques. Tome 1 - Ostéologie. Paris: Vigot, $761 \mathrm{p}$.

BEAUVAL C. et MORIN E. 2010 - Les repaires d'hyènes du Lussacois (Lussac-les-Châteaux, Vienne, France). Apport des sites des Plumettes et des Rochers-de-Villeneuve. In : BUISSON-CATIL J. et PRIMAULT J. (eds.), Préhistoire entre Vienne et Charente. Hommes et sociétés du Paléolithique. Villefranche-de-Rouergue: Ministère de la Culture et de la Communication, Mémoire 38 de l'Association des Publications Chauvinoises, p. 175-189.

BEZ J.-F. 1995 - Une expérience de découpe bouchère pratiquée au silex : aspects anatomiques. Préhistoire Anthropologie Méditerranéennes, 4, p. 41-50.

BIGNON O. 2006 - Approche morphométrique des dents jugales déciduales d'Equus caballus arcelini (sensu lato, Guadelli 1991) : critères de détermination et estimation de l'âge d'abattage. Compte Rendu Palevol, 5, p. 1005-1020.

BINFORD L.R. 1978 - Nunamiut Ethnoarchaeology. New-York: Academic Press, 509 p.

BINFORD L.R. 1980 - Willow Smoke and Dogs' Tails: Hunter-Gatherer Settlement Systems and Archaeological Site Formation. American Antiquity, 45, 1, p. 4-20.

BINFORD L.R. 1981 - Bones: Ancient Men and Modern Myths. Academic Press, 320 p.

BLAIR E.H. 1996 - The Indian Tribes of the Upper Mississippi Valley \& Region of the Great Lakes: As Described by Nicolas Perrot, French Commandant in the Northwest. University of Nebraska Press, 414 p.

BOCHERENS H., FIZET M. et MARIOTTI A. 1990 - Mise en évidence du régime alimentaire végétarien de l'ours des cavernes (Ursus spelaeus) par la biogéochimie isotopique $(13 \mathrm{C}, 15 \mathrm{~N}) \mathrm{du}$ collagène fossile. Compte Rendu de l'Académie des Sciences de Paris, 311, p. 1279-1284.

BON F. 2002 - L'Aurignacien entre Mer et Océan : Réflexion sur l'unité des phases anciennes de l'Aurignacien dans le sud de la France. Mémoire de la Société Préhistorique Française, 256 p.

BORDES J.-G. 2002 - Les interstratifications Châtelperronien/Aurignacien du Roc de Combe et du Piage (Lot, France) : analyse taphonomique des industries lithiques, implications archéologiques. Thèse de doctorat, Université de Bordeaux I, 365 p.

BRUGAL J.-P. et DAVID F. 1993 - Usure dentaire, courbe de mortalité et « saisonnalité » : les gisements du Paléolithique moyen à Grands Bovidés. In : DESSE J. et AUDOIN-ROUZEAU F. (eds.), Exploitation des animaux sauvages à travers le temps, Actes des XIII ${ }^{e}$ rencontres internationales d'Archéologie et d'Histoire d'Antibes. Juan-les-Pins: APDCA, p. 64-67. 
BUNN H.T., BARTRAM L.E. et KROLL E.M. 1988 - Variability in Bone Assemblage Formation from Hadza Hunting, Scavenging, and Carcass Processing. Journal of Anthropological Archaeology, 7, p. 412-457.

BURCH E.S. 1972 - The Caribou/Wild Reindeer as a Human Resource. American Antiquity, 37, 3, p. 339-368.

CASTEL J.-C. 2011 - Archéozoologie de l'Aurignacien de l'Abri Castanet (Sergeac, Dordogne, France) : les fouilles 1994-1998. Revue de Paléobiologie, 30, 2, p.-783-815.

CASTEL J.-C. et MADELAINE S. 2003 - Stigmates observés sur les dents de grands carnivores à l'Aurignacien. L'exemple de l'Abri de La Souquette à Sergeac (Dordogne, France). Paleo, 15, p. 251-254.

CASTEL J.-C., CHAUVIÈRE F.-X. et MADELAINE S. 2003 - Sur os et sur dents : les « retouchoirs » aurignaciens de la Ferrassie (Savignac-de-Miremont, Dordogne). Paleo, 15, p. 29-50.

CHURCH R.R. et LYMAN R.L. 2003 - Small fragments make small differences in efficiency when rendering grease from fractured artiodactyl bones by boiling. Journal of Archaeological Science, 30, 8, p. 1077-1084.

COSTAMAGNO S. 1999 - Stratégies de chasse et fonction des sites au Magdalénien dans le Sud de la France. Thèse de doctorat, Université de Bordeaux I, 495 p.

COSTAMAGNO S. et DAVID F. 2009 - Comparaison des pratiques bouchères et culinaires de différents groupes sibériens vivant de la renniculture. Archaeofauna, 19, p. 9-25.

COSTAMAGNO S., THÉRY-PARISOT I., CASTEL J.-C. et BRUGAL J.-P. 2009 - Combustible ou non? Analyse multifactorielle et modèles explicatifs sur des ossements brûlés paléolithiques. In : THÉRY-PARISOT I., COSTAMAGNO S. et HENRY A. (eds.), Gestion des combustibles au Paléolithique et au Mésolithique : nouveaux outils, nouvelles interprétations. XV Congrès de l'UISPP, septembre 2006, Lisbonne. BAR International Series, vol. 1914, p. 65-84.

CURTIS E.S. 1930 - The North American Indian. Weston La Barre, 409 p.

DARWENT C.M. et LYMAN R.L. 2002 - Detecting the Postburial Fragmentation of Carpals, Tarsals, and Phalanges. In : HAGLUND W. D. et SORG M. H. (eds.), Advances in Forensic Taphonomy: Method, Theory, and Archaeological Perspectives. Boca Raton, FL.: CRC Press, p. 355-377.

DISCAMPS E. 2011 - Hommes et hyènes face aux recompositions des communautés d'Ongulés (MIS 5-3) : Éléments pour un cadre paléoécologique des sociétés du Paléolithique moyen et supérieur ancien d'Europe de l'Ouest. Thèse de doctorat, Université de Bordeaux I, 437 p.

DISCAMPS E., JAUBERT J. et BACHELLERIE F. 2011 - Human choices and environmental constraints: deciphering the variability of large game procurement from Mousterian to Aurignacian times (MIS 5-3) in southwestern France. Quaternary Science Reviews, 30, p. 2755-2775.

DUNCAN P.B. 1992 - Horses and grasses: the nutritional ecology of equids and their impact on the Camargue. New-York: Springer verlag, $287 \mathrm{p}$.

EIZENBERG L. 2006 - Le rôle de l'Aurignacien archaïque dans les phases initiales du Paléolithique supérieur : apports des industries lithiques de la grotte des Abeilles (Haute-Garonne). Mémoire de Master 2, Université de Toulouse-Le Mirail, 68 p.

EKBLAW W.E. 1928 - The Material Response of the Polar Eskimo to Their Far Arctic Environment (Continued). Annals of the Association of American Geographers, 18, 1, p. 1-24.

EMERSON A.M. 1990 - Archaeological Implications of variability in the economic anatomy of Bison bison. Thèse de doctorat, Washington State University, 896 p. 
FISCHER J.W. 1995 - Bone Surface Modifications in Zooarchaeology. Journal of Achaeological Method and Theory, 2, 1, p. 7-68.

FLEMING R. et THEODORA H. 1979 - Ishi, the Last Yahi: A Documentary History. University of California Press, 256 p.

FRISON G.C., WILSON M. et WILSON D.J. 1976 - Fossil bison and artifacts from an early Altithermal period arroyo trap in Wyoming. American Antiquity, 41, 1, p. 28-57.

GAMBIER D. 1992 - Vestiges humains du Paléolithique supérieur. Inventaire et description préliminaire de spécimens inédits des collections du Musée national de Préhistoire (Les Eyziesde-Tayac). Paleo, 4, 91-100.

GRAYSON D.K. et DELPECH F. 2002 - Specialized Early Upper Palaeolithic Hunters in Southwestern France? Journal of Archaeological Science, 29, p. 1439-1449.

GRAYSON D.K. et DELPECH F. 2006 - Was there Increasing Dietary Specialization Across the Middle-to-Upper Paleolithic Transition in France? In: CONARD N. (ed.) When Neanderthals and Modern Humans Met. Tübingen: Kerns Verlag, p. 377-417.

GRAYSON D.K., DELPECH F. et RIGAUD J.P. 2001 - Explaining the Development of Dietary Dominance by a Single Ungulate Taxon at Grotte XVI, Dordogne, France. Journal of Archaeological Science, 28, p. 115-125.

GRØNNOW B., MELDGAARD M. et NIELSEN J.B. 1983 - Aasivissuit, the Great Summer Camp: Archaeological, Ethnographical and Zoo-archaeological Studies of a Caribou-hunting Site in West Greenland. Man \& Society, $96 \mathrm{p}$.

HABERMEHL K.-H. 1975 - Die Altersbestimmung bei Haus- und Labortieren. Berlin-Hambur: Verlag Paul Parey, 216 p.

HOLSTON W.E. 1963 - The Diet of the Mountain Men. California Historical Society Quarterly, 42, 4, p. 301-309.

HOUSTON S., BALL T. et HOUSTON M. 2003 - Eighteenth-Century Naturalists of Hudson Bay. McGillQueen's University Press, $432 \mathrm{p}$.

HUNGRY WOLF B. 1980 - The Ways of My Grandmothers. William Morrow \& Co, 256 p.

INGSTAD H. 1992 - The Land of Feast and Famine. McGill-Queen's University Press, 360 p.

JENNESS D. 1923 - The Life of the Copper Eskimos. Report of the Canadian Arctic Expedition 1913-18, vol. XII, p. 277.

JIN J.J.H. et MILLS E.W. 2011 - Split phalanges from archaeological sites: Evidence of nutritional stress? Journal of Archaeological Science, 38, 8, p.1798-1809.

JULIEN M., BAFFIER D. et LIOLIOS D. 2002 - L'outillage en matières dures animales. In : SCHMIDER B. (ed.) L'Aurignacien de la grotte du Renne : Les fouilles d'André Leroi-Gourhan à Arcy-sur-Cure (Yonne). Paris: CNRS (XXXIV e suppl. à Gallia Préhistoire), p. 217-250.

KELSALL J.P. 1968 - The Caribou Ottawa: Canadian Wildlife Service, 340 p.

KENT S. 1993 - Variability in Faunal Assemblages: The Influence of Hunting Skill, Sharing, Dogs, and Mode of Cooking on Faunal Remains at a Sedentary Kalahari Community. Journal of Anthropological Archaeology, 12, 4, p. 323-385.

KNECHT H. 1991 - The Role of Innovation in changing Early Upper Paleolithic organic Projectile Technologies. Techniques et culture, 17, 8, p. 115-144. 
KNECHT H. 1993 - Early Upper Paleolithic Approaches to Bone and Antler Projectile Technology. In: PETERKIN G. L., BRICKER N. M. et MELLARS P. (eds.), Hunting and Animal Exploitation in the Later Palaeolithic and Mesolithic of Eurasia. Special Issue (vol. 4, Issue 1). Archeological Papers of the American Anthropological Association, p. 33-47.

KREUTZER L.A. 1992 - Bison and Deer Bone Mineral Densities: Comparisons and Implications for the Interpretation of Archaeological Faunas. Journal of Archaeological Science, 19, p. 271-294.

LAM Y.M., CHEN X. et PEARSON O.M. 1999 - Intertaxonomic Variability in Patterns of Bone Density and the Differential Representation of Bovid, Cervid, and Equid Elements in the Archaeological Record. American Antiquity, 64, 2, p. 343-362.

LAPLACE G. 1966 - Recherches sur l'origine et l'évolution des complexes leptolithiques. Paris: Ed. de Boccard, $586 \mathrm{p}$.

LAPLACE G. 1971 - De l'application des coordonnées cartésiennes à la fouille stratigraphique. Munibe, XXIII, p. 223-236.

LAPLACE G. et MÉROC L. 1954 - Application des coordonnées cartésiennes à la fouille d'un gisement. Bulletin de la Société préhistorique française, 51, 1-2, p. 58-66.

LAPLACE G., BARANDIARÁN I., SAENZ DE BURUAGA A. et ALTUNA J. 2006 - Les Aurignaciens pyrénéens des Abeilles et méditerranéen de Régismont-le-Haut, Analyses typologique et paléontologique. Les Eyzies-de-Tayac: SAMRA, 154 p.

LARIVIÈRE S. et PASITSCHNIAK-ARTS M. 1996 - Vulpes Vulpes. Mammalian Species, 537, p. 1-11.

LEECHMAN D. 1951 - Bone Grease. American Antiquity, 16, 4, p. 335-356.

LEROY-PROST C. 1974 - Les pointes en matière osseuse de l'Aurignacien. Caractéristiques morphologiques et essais de définition. Bulletin de la Société préhistorique française, 71, 2, p. 449-458.

LEROY-PROST C. 1975 - L'industrie osseuse aurignacienne. Essai régional de classification : Poitou, Charentes, Périgord. Gallia préhistoire, 18, 1, p. 65-156.

LEROY-PROST C. 1979 - L'industrie osseuse aurignacienne. Essai régional de classification : Poitou, Charentes, Périgord (suite). Gallia préhistoire, 22, 1, p. 205-370.

LETOURNEUX C. 2003 - Devine qui est venu dîner à Brassempouy? Approche taphonomique pour une interprétation archéozoologique des vestiges osseux de l'Aurignacien ancien de la grotte des Hyènes (Brassempouy, Landes). Thèse de Doctorat de l'Université de Paris I, 603 p.

LÉVINE M.A. 1979 - Archaeo-Zoological Analysis of Some Upper Pleistocene Horse Bone Assemblages in Western Europe. Thèse de doctorat, University of Cambridge, $372 \mathrm{p}$.

LIOLIOS D. 1999 - Variabilité et caractéristiques du travail des matières osseuses au début de l'Aurignacien : approche technologique et économique. Thèse de doctorat, Université de Paris XNanterre, 1999. 360 p.

LIOLIOS D. 2006 - Reflections on the role of bone tools in the definition of the Early Aurignacian. In: BAR-YOSEF O. et ZILHÃO J. (eds.), Towards a definition of the Aurignacian. Lisbonne: Instituto Poruguese de Arqueologia (Trabalhos de Arqueologia, 45), p. 37-51.

LUPO K.D. et SCHMITT D.N. 1997 - Experiments in bone boiling: nutritional returns and archaeological reflections. Anthropozoologica, 25-26, p. 137-144.

MALLYE J.-B. 2011 - Réflexion sur le dépouillement des petits carnivores en contexte archéologique : apport de l'expérimentation. Archaeofauna, 20, p. 7-25. 
MAREAN C.W. et CLEGHORN N. 2003 - Large Mammal Skeletal Element Transport: Applying Foraging Theory in a complex Taphonomic System. Journal of Taphonomy, 1, 1, p. 15-42.

MÉROC L. 1948 - Montmaurin (Coupe-Gorge, Montmaurin, Terrasse, Zubiate, les Abeilles). Informations préhistoriques. Xe circonscription. Gallia, VI, p. 409-412.

MÉROC L. 1963 - Les éléments de datation de la mandibule humaine de Montmaurin (HauteGaronne). Bull. soc. géol. de France, V, p. 508-515.

METCALFE D. et JONES K.T. 1988 - A reconsideration of animal body part utility indices. American Antiquity, 53, 3, p. 486-504.

MILLER F.L. 1974 - Biology of the Kaminuriak population of barren-ground caribou. Part 2: Dentition as indicator of age and sex; composition and spezialization of the population. Canadian Wildlife Service Report Series, 31, $88 \mathrm{p}$.

MOREL P. et MÜLLER W. 1997 - Hauterive-Champréveyres : un campement magdalénien au bord du lac de Neuchâtel. Étude archéozoologique. Neuchâtel: Archéologie neuchâteloise, 149 p.

MORIN E. 2007 - Fat composition and Nunamiut decision-making: a new look at the marrow and bone grease indices. Journal of Archaeological Science, 34, p. 69-82.

MORIN E. 2008 - Evidence for declines in human population densities during the early Upper Paleolithic in western Europe. PNAS, 105, 1, p. 48-53.

MORIN E. 2012 - Reassessing paleolithic subsistence: the Neandertal and modern human foragers of SaintCésaire. Cambridge University Press, 358 p.

NILSSEN P.J. 2000 - An actualistic butchery study in South Africa and its implications for reconstructing hominid strategies of carcass acquisition and butchery in the upper Pleistocene and Plio-Pleistocene. Thèse de doctorat, University of Cape Town, $649 \mathrm{p}$.

NORMAND C. 2005 - Les occupations aurignaciennes de la grotte d'Isturitz (Saint-Martind'Arberoue ; Pyrénées-Atlantiques ; France) : synthèse des données actuelles. Munibe (Antropologia-Arkeologia), 57, Homenaje a Jesús Altuna, p. 119-129.

OUTRAM A. et ROWLEY-CONWY P. 1998 - Meat and marrow utility indices for horse (Equus). Journal of Archaeological Science, 25, p. 839-849.

OUTRAM A.K. 2001 - A New Approach to Identifying Bone Marrow and Grease Exploitation: Why the "Indeterminate" Fragments should not be Ignored. Journal of Archaeological Science, 28, p. 401-410.

OUTRAM A.K. 2002 - Bone Fracture and Within-Bone Nutrients: An Experimentally Based Method for Investigating Levels of Marrow Extraction. In: MIRACLE P. et MILNER N. (eds.), Consuming Passions and Patterns of Consumption. Cambridge: McDonald Institute for Archaeological Research, p. 51-64.

OUTRAM A.K. 2005 - Distinguishing bone fat exploitation from other taphonomic what the high level of bone fragmentation at the Middle Neolithic site of Ajvide, Gotland? In: MULVILLE J. et OUTRAM A. (eds.), The zooarchaeology of fats, oils, milk and dairying. Oxford: Oxbow Books, p. 32-43.

PARGET A.M. 2004 - The People of the Plains. University of Regina. Canadian Plains Research Center, $78 \mathrm{p}$.

PASDA K. 2013 - Caribou hunting and utilization in West Greenland: Past and present variants. Anthropozoologica, 48, 1, p. 111-123. 
PECK T.E. 2004 - Bison Ethology and Native Settlement Patterns during the Old Women's Phase on the Northwestern Plains. BAR Series 1278, 147 p.

PELEGRIN J. 1990 - Observations technologiques sur quelques séries du Châtelperronien et du MTA B du sud-ouest de la France. Une hypothèse d'évolution. In: FARIZY C. (ed.) Paléolithique moyen récent et Paléolithique supérieur ancien en Europe, actes du colloque international de Nemours. Mémoire du Musée de Préhistoire d'Ile-de-France, p. 195-201.

PINSON E.B. 2004 - Alaska's Daughter. An Eskimo Memoir of the Early Twentieth Century. Logan: Utah State University Press, $212 \mathrm{p}$.

ROINE K., NIEMINEN M. et TIMISJÄVI J. 1982 - Foetal Growth in the Reindeer. Acta vet. scand., 23, p. 107-117.

ROUSSEL M. 2011 - Normes et variations de la production lithique durant le Châtelperronien : la séquence de la Grande-roche-de-la-Plématrie à quinçay (Vienne). Thèse de doctorat, Université de Paris Ouest Nanterre, 540 p.

RUSSELL P.N. 1995 - Some Large Game Animal Traditions of the Inland Dena'Ina. University of Alaska, $15 \mathrm{p}$.

SAINT-GERMAIN C. 2005 - Animal fat in the cultural world of the Native Peoples of Northeastern America. In: MULVILLE J. et OUTRAM A. (eds.), The zooarchaeology of fats, oils, milk and dairying. Oxford: Oxbow Books, p. 107-113.

SEKHR A. 1998 - Étude archéozoologique des niveaux aurignaciens (couches 14 à 6) et de la base des niveaux gravettiens (niveaux X à T4) de l'abri Pataud (Les Eyzies, Dordogne). Thèse de doctorat, Muséum National d'Histoire Naturelle de Paris, 346 p.

SIMONNET R. 1979 - Les habitats préhistoriques des gorges de la Save dans le massif de LespugueMontmaurin. In : SACCHI D. (ed.) Le Pléistocène supérieur en France : IIIe colloque Franco-Soviétique Dynamique des interactions entre le milieu naturel et les sociétés préhistoriques, 10-25 septembre 1979. p. 155-162.

SOPER J.D. 1941 - History, Range, and Home Life of the Northern Bison. Ecological Monographs, 11, 4, p. $347-412$.

SOULIER M.-C. 2013 - Entre alimentaire et technique : l'exploitation animale aux débuts du Paléolithique supérieur. Stratégies de subsistance et chaînes opératoires de traitement du gibier à Isturitz, La Quina aval, Roc-de-Combe et Les Abeilles. Thèse de doctorat, Université de Toulouse-Le Mirail, 754 p.

SOULIER M.-C., GOUTAS N., NORMAND C., LEGRAND A. et WHITE R. 2014 - Regards croisés de l'archéozoologue et du technologue sur l'exploitation des ressources animales à l'Aurignacien archaïque : l'exemple d'Isturitz (Pyrénées-Atlantiques, France). In : THIÉBAULT C., CLAUD É. et COSTAMAGNO S. (eds.), Transitions, ruptures et continuité en Préhistoire. Vol.2 : Exploitation des ressources organiques à la fin du Paléolithique moyen et au début du Paléolithique supérieur : interactions entre environnement et comportements techniques. XXVII ${ }^{\mathrm{e}}$ congrès préhistorique de France, Bordeaux-Les Eyzies, 31 mai-5 juin 2010: Mémoires de la SPF, p. 315-332.

SPECK F.G. 1935 - Naskapi: The Savage Hunters of the Labrador Peninsula. University of Oklahoma Press, $257 \mathrm{p}$.

SPETH J.D. 1983 - Bison Kills and Bone Counts: Decision Making by Ancient Hunters. University of Chicago Press, $272 \mathrm{p}$.

STEFANSSON V. 2004 (rééd. 1913) - My Life With The Eskimo. Kessinger Publishing, 672 p. 
STOPP M.P. 2000 - Après la capture des phoques et des caribous. Une reformulation des modèles d'adaptation dans le Subarctique oriental. Recherches amérindiennes au Québec, 2, p. 51-62.

TABORIN Y. 1990 - Les prémices de la parure. In: FARIZY C. (ed.) Paléolithique moyen récent et Paléolithique supérieur ancien en Europe. Mémoire du Musée de Préhistoire d'Ile-de-France (3), p. 335-344.

TABORIN Y. 2002 - Les objets de parure. In: SCHMIDER B. (ed.) L'Aurignacien de la Grotte-du-Renne, XXXIVe supplément à Gallia Préhistoire. CNRS Éditions, p. 253-256.

TARTAR É. 2009 - De l'os à l'outil. Caractérisation technique, économique et sociale de l'utilisation de l'os à l'Aurignacien ancien. Étude de trois sites : l'Abri Castanet (secteurs nord et sud), Brassempouy (Grotte des Hyènes et Abri Dubalen) et Gatzarria. Thèse de doctorat, Université de Paris I - Panthéon Sorbonne, $375 \mathrm{p}$.

TEYSSANDIER N. 2007 - En route vers l'Ouest. Les débuts de l'Aurignacien en Europe. BAR International Series $1638,312 \mathrm{p}$.

THIÉBAUT C., CLAUD E., COSTAMAGNO S., COUDENNEAU A., DESCHAMPS M., MOURRE V., VAL A., BRENET M., CHACÓN M.-G., CHONG S., COUMONT M.-P., COLONGE D., GERBE M., MUSSINI C. et SOULIER M.-C. 2011 - Des traces et des hommes : Projet de recherche interdisciplinaire sur l'identification des modalités d'acquisition et de traitement des matières végétales et animales au Paléolithique moyen en Europe occidentale. Rapport. SRA Midi-Pyrénées, 222 p.

VANHAEREN M. 2002 - Les fonctions de la parure au Paléolithique supérieur : de l'individu à l'unité culturelle. Thèse de doctorat, Université de Bordeaux I, 355p.

VIGNE J.-D. 2005 - Découpe du cerf (Cervus elaphus) au Mésolithique moyen, à Noyen-sur-Seine (Seine-et-Marne) : analyses tracéologique et expérimentale. Revue de Paléobiologie, 10, p. 69-82.

VIGNE J.-D., MARINVAL-VIGNE M.C., LANFRANCHI F.D. et WEISS M.C. 1981 - Consommation du « Lapin-rat » (Prolagus sardus Wagner) au Néolithique ancien méditerranéen. Abri d'AraguinaSennola (Bonifacio, Corse). Société Préhistorique Française, 78, p. 222-224.

VILLA P. et MAHIEU E. 1991 - Breakage patterns of human long bones. Journal of Human Evolution, 21,1, p. $27-48$.

VILLA P., CASTEL J.-C., BEAUVAL C., BOURDILLAT C. et GOLDBERG P. 2004 - Human and carnivore sites in the European Middle and Upper Paleolithic: similarities and differences in bone modification and fragmentation. Revue de Paléobiologie, 23, 2, p. 705-730.

WHEAT J.B., MALDE H.E. et LEOPOLD E.B. 1972 - The Olsen-Chubbuck Site: A Paleo-Indian Bison Kill. Society for American Archaeology, $180 \mathrm{p}$.

WHITE R. 1997 - Substantial acts: From materials to meaning in Upper Paleolithic representation. In: CONKEY M., SOFFER O., STRATMANN D. et JABLONSKI N. G. (eds.), Beyond Art: Pleistocene Image and Symbol. San Francisco: Memoirs of the California Academy of Sciences, 23, p. 93-121.

WHITE R. 2002 - Observations technologiques sur les objets de parure. In : SCHMIDER B. (ed.) L'Aurignacien de la grotte du Renne. Les fouilles d'André Leroi-Gourhan à Arcy sur Cure (Yonne). Paris: $\mathrm{XXXIV}^{\mathrm{e}}$ supplément à Gallia Préhistoire. CNRS éditions, p. 257-266.

WHITE R. 2010 - Les parures de l'Aurignacien ancien et archaïque. Perspectives technologiques et régionales des fouilles récentes. In : MISTROT V. (ed.) De Néandertal à l'Homme moderne : l'Aquitaine préhistorique, vingt ans de découvertes (1990-2010). Bordeaux: Editions Confluences, p. 93-103. 


\section{NOTES}

2. For a mandible fragment with several teeth, the Number of Specimens (NS) was noted as equal to 1 .

3. Confrontation of available reference sources in Soulier 2013.

4. This material is currently under study by É. Tartar.

\section{ABSTRACTS}

The cave of Les Abeilles, which was excavated from 1945-1951, comprises archaeological layers that document the early phases of the Upper Palaeolithic in Europe. The Protoaurignacian and Early Aurignacian layers contain several human remains, as well as an abundant lithic material. A large number of faunal remains have been uncovered in these layers, including some that were transformed into tools and ornaments. The present study is concerned with the entire faunal material, including food debris and remains used for technical or ornamental purposes. The archaeozoological analysis of the Protoaurignacian and Early Aurignacian layers show similarities (hunting seasons, carcass transport decisions) as well as differences (e.g., dismembering, marrow processing) in carcass processing. By examining the entire faunal material, this study shows that the dietary, technical and symbolic spheres are strongly interconnected in both layers, and this in a complex way. The decisions that were made influenced the entire processing sequence (prey acquisition, butchery processes, etc.). Comparisons of these data with coeval assemblages highlight the fact that early Upper Palaeolithic groups used a wide range of responses to fulfill their particular needs.

La grotte des Abeilles, fouillée entre 1945 et 1951, a livré des niveaux archéologiques documentant notamment les premières phases du Paléolithique supérieur en Europe. Ces séries, attribuées au Protoaurignacien et à l'Aurignacien ancien, se composent de plusieurs restes humains, d'un abondant matériel lithique et de nombreux vestiges fauniques dont certains ont été transformés en outils et en éléments de parure. L'étude présentée ici concerne l'ensemble du matériel faunique, soit les restes utilisés à des fins alimentaires, techniques et ornementales. Les analyses archéozoologiques des niveaux attribués au Protoaurignacien et à l'Aurignacien ancien illustrent à la fois des similitudes (saisons de capture du gibier, modes de transport des carcasses) et des différences (e.g. désarticulation, techniques de récupération de la moelle osseuse) dans les modalités d'exploitation alimentaire du gibier. La prise en compte de l'ensemble du matériel faunique a permis de montrer que les sphères alimentaire, utilitaire et symbolique s'enchevêtrent de manière complexe dans les deux ensembles et que les choix effectués se répercutent sur l'ensemble de la chaîne d'exploitation (acquisition du gibier, modalités de boucherie, etc.). Les données acquises, confrontées à celles disponibles pour d'autres séries de cette même période, soulignent la diversité des réponses adoptées par les groupes humains du début du Paléolithique supérieur pour satisfaire au mieux à des besoins spécifiques. 


\section{INDEX}

Mots-clés: Paléolithique supérieur, archéozoologie, Protoaurignacien, Aurignacien ancien, SudOuest de la France, modalités de boucherie, exploitation utilitaire-symbolique de la faune, chaîne opératoire d'exploitation de la faune

Keywords: Upper Palaeolithic, zooarchaeology, Protoaurignacian, Early Aurignacian, southwestern France, carcass processing, domestic and symbolic use of the fauna, sequence of exploitation of animals

\section{AUTHOR}

\section{MARIE-CÉCILE SOULIER}

Trent University, Dept. of Anthropology, DNA Block C, 2140 East Bank Drive, Peterborough, ON, K9J 7B8 Canada et Université de Toulouse-Le Mirail TRACES UMR 5608 CNRS, Maison de la Recherche, 5 allées Antonio Machado, FR-31058 Toulouse Cedex 9 - mariecsoulier@gmail.com 